Neurobiology of Disease

$37,423-433$

\title{
Dissociation of AGAT, GAMT and SLC6A8 in CNS: Relevance to creatine deficiency syndromes.
}

\section{Olivier Braissant, Elidie Béard, Céline Torrent and Hugues Henry}

\author{
Inborn Errors of Metabolism, \\ Clinical Chemistry Laboratory, \\ Centre Hospitalier Universitaire Vaudois and University of Lausanne, \\ CH-1011 Lausanne, Switzerland.
}

\section{Correspondence to: Dr. Olivier Braissant,}

Inborn Errors of metabolism, Clinical Chemistry Laboratory,

Centre Hospitalier Universitaire Vaudois and University of Lausanne, CI 02/33, Avenue Pierre-Decker 2, CH-1011 Lausanne, Switzerland Tél : (+41.21) 314.41.52, Fax : (+41.21) 314.35.46

e-mail : Olivier.Braissant@chuv.ch 


\begin{abstract}
AGAT and GAMT, the two enzymes of the creatine synthesis pathway, are well expressed within CNS, suggesting autonomous brain creatine synthesis. This contradicts SLC6A8 deficiency, which causes creatine deficiency despite CNS expression of AGAT and GAMT. We hypothesized that AGAT and GAMT were not co-expressed by brain cells, and that guanidinoacetate must be transported between cells to allow creatine synthesis. We finely analyzed the cell-to-cell co-expression of AGAT, GAMT and SLC6A8 in various regions of rat $\mathrm{CNS}$, and showed that in most structures, cells co-expressing AGAT+GAMT (equipped for autonomous creatine synthesis) were in low proportions $(<20 \%)$. Using reaggregating brain cell cultures, we also showed that brain cells take up guanidinoacetate and convert it to creatine. Guanidinoacetate uptake was competed by creatine. This suggests that in most brain regions, guanidinoacetate is transported from AGAT- to GAMT-expressing cells through SLC6A8 to allow creatine synthesis, thereby explaining creatine deficiency in SLC6A8deficient CNS.
\end{abstract}

\title{
Keywords
}

Creatine, guanidinoacetate, brain, creatine deficiency syndromes, rat 


\section{Introduction}

In mammals, creatine $(\mathrm{Cr})$ is taken from diet or synthesized by a two-step mechanism involving L-arginine:glycine amidinotransferase (AGAT) yielding guanidinoacetate (GAA) as intermediate, and guanidinoacetate methyltransferase (GAMT) converting GAA to Cr. Cells take up Cr through a specific transporter, SLC6A8 (Wyss \& Kaddurah-Daouk, 2000).

Central nervous system (CNS) is the main organ affected in $\mathrm{Cr}$ deficiency syndromes caused by AGAT, GAMT or SLC6A8 deficiency (Stöckler et al., 1994; Schulze et al., 1997; Salomons et al., 2001; Item et al., 2001). These patients present neurological symptoms in infancy, including mental retardation and delays in speech acquisition. GAMT, and often SLC6A8 deficiencies, also cause epilepsy. Cr deficiencies are characterized by strongly decreased Cr levels in CNS, as measured by magnetic resonance spectroscopy (MRS). AGAT- and GAMT-deficient patients can be treated with oral $\mathrm{Cr}$ supplementation, while $\mathrm{Cr}$ supplementation of SLC6A8-deficient patients does not restore brain Cr (Stöckler et al., 2007; Schulze \& Battini, 2007).

Brain cells synthesize Cr, as shown in organotypic cultures (Braissant et al., 2002; Almeida et al., 2006). In vivo, AGAT and GAMT are found in all brain cell types (neurons, astrocytes, oligodendrocytes); SLC6A8 is expressed in neurons and oligodendrocytes but not in astrocytes, and is present in microcapillary endothelial cells (MCEC) forming blood brain barrier (BBB) (Braissant et al., 2001a; Ohtsuki et al., 2002; Schmidt et al., 2004; Tachikawa et al., 2004). Apart of BBB, astrocyte feet around MCEC are more and more recognized as true regulators of water and metabolite exchanges between periphery and CNS (Nedergaard et al., 2003). SLC6A8 absence from astrocytes suggested thus that BBB has a limited 
permeability for $\mathrm{Cr}$ (Braissant et al., 2001a). This is supported in vivo: the blood to brain $\mathrm{Cr}$ transport appears relatively inefficient in rodents (Ohtsuki et al., 2002; Perasso et al., 2003) and the replenishement of CNS $\mathrm{Cr}$ pools in AGAT- and GAMT-deficient patients supplemented with high doses of $\mathrm{Cr}$ is slow and only partial (Schulze \& Battini, 2007). Moreover, Cr levels are normal in CSF of SLC6A8-deficient patients unable of Cr import from periphery, while they are strongly decreased in CSF of GAMT-deficient patients who can import Cr from periphery (Braissant \& Henry, 2008).

These observations suggest that CNS depends more on autonomous $\mathrm{Cr}$ synthesis than on supply from periphery. This seems contradictory with SLC6A8-deficient patients who, despite AGAT and GAMT expression in CNS, show strongly decreased levels of brain Cr. We hypothesized that the brain cell-to-cell AGAT, GAMT and SLC6A8 expression pattern might explain this contradiction: AGAT and GAMT, which can be found in every CNS cell types, might not be co-expressed within the same cells. That would also imply that GAA must be transported between brain cells for $\mathrm{Cr}$ synthesis to occur. This work aimed at dissecting the cell-to-cell co-expression of AGAT, GAMT and SLC6A8 within various regions of rat CNS. Moreover, brain cell GAA uptake and its conversion to $\mathrm{Cr}$ were analyzed by tandem mass spectrometry in reaggregated brain cell primary cultures, which synthesize $\mathrm{Cr}$ and express AGAT, GAMT and SLC6A8 as CNS in vivo (Braissant et al., 2008). 


\section{Materials and Methods}

\section{Preparation of adult rat brains}

Animal procedures were in compliance with the directives of the Swiss Academy of Medical Science. Adult rats (Sprague-Dawley, 300g, Harlan, Netherlands) were sacrificed by decapitation. Their brain was extracted within $2 \mathrm{~min}$, rinsed in diethylpyrocarbonate-treated PBS, and immediately embedded in tissue freezing medium (Tissue-Tek, Sakura Finetek, Netherlands), frozen in liquid nitrogen-cooled isopentane and stored at $-80^{\circ} \mathrm{C}$.

\section{In situ hybridization and immunohistochemistry}

AGAT, GAMT and SLC6A8 expression was analyzed within various representative regions of the rat brain (Figure 1 and Supplementary Table 1) by in situ hybridization (ISH) coupled to immunohistochemistry, allowing the detection of both mRNA and protein for AGAT, GAMT and SLC6A8 genes. To achieve this, specific RNA probes and antibodies were applied to rat brain cryosections ( $12 \mu \mathrm{m}$ thick). ISH was performed by hybridizing digoxigenin-labeled antisense and sense riboprobes specific for rat AGAT, GAMT and SLC6A8 as described in details (Braissant et al., 2001a). Sections were stained with alkalinephosphatase using nitroblue-tetrazolium and 5-bromo-4-chloro-3-indolyl-phopshate (blue signal). After staining, sections were dehydrated. The hybridization specificity was ascertained by the negative staining of ISH sense control probes-hybridized sections for AGAT, GAMT and SLC6A8 (data not shown). Sense probes-hybridized sections were mounted (Eukitt, O.Kindler, Germany). Antisense probes-hybridized sections were processed for immunohistochemistry as described in details (Braissant, 2004), using specific antiAGAT, -GAMT and -SLC6A8 rabbit polyclonal antibodies already characterized (Braissant et al., 2005), or alternatively anti-glial fibrillary acidic protein (GFAP) or anti-NeuN mouse monoclonal antibodies (Chemicon International). Sections were stained using horse radish 
peroxidase, the Histostain-Plus kit (Zymed Laboratories) and aminoethyl-carbazole $/ \mathrm{H}_{2} \mathrm{O}_{2}$ (red signal).

The double-stained sections (ISH blue, immunohistochemistry red) were mounted in glycerol. AGAT, GAMT and SLC6A8 patterns were considered specific and validated by the excellent correlation, in all CNS regions, between signals observed by ISH (mRNA) and immunohistochemistry (protein), the negative signals observed with ISH sense probes, and the absence of labeling in immunohistochemical controls without primary antibodies or in presence of pre-immune serum (data not shown, and Braissant et al., 2005). The ISH protocol sensitivity, which can detect as low as 15 transcripts per cell, has been described elsewhere (Braissant et al., 2001b; Braissant, 2004).

\section{Histological analysis and cell counting}

Sections were observed on an Olympus BX50 microscope equipped with a ColorView-II camera (Olympus Opticals, Japan). Brain structures were identified according to Paxinos and Watson (1986) (Supplementary Table 1). In each brain structure, cells were counted within a square surface of $200 \mu \mathrm{m} \times 160 \mu \mathrm{m}(12 \mu \mathrm{m}$ thick cryosections), except for CA3 pyramids and dentate gyrus granular neurons (hippocampus), and for Purkinje neurons (cerebellum), where cells were counted along $200 \mu \mathrm{m}$ (hippocampus) or $500 \mu \mathrm{m}$ (Purkinje neurons) of these linear structures. Cell counting was achieved with the help of the Cell ${ }^{\mathrm{F}}$ software (Olympus). The average number of cells counted per brain and per co-labeling experiment is indicated in Supplementary Table 1. While AGAT, GAMT and SLC6A8 proteins can be localized far from soma (e.g: cell processes), they are also present, when expressed, in soma (AGAT and GAMT) or at its surface (SLC6A8) (Tachikawa et al., 2004; Braissant et al., 2008; Tachikawa et al., 2008). Therefore, to be coherent with ISH counting (mRNA, essentially localized around nucleus), brain cells were counted positive for AGAT, GAMT or SLC6A8 proteins 
only if their soma showed the immunohistochemistry signal.

The 3 different " 2 by 2" combinations (AGAT+GAMT; AGAT+SLC6A8; GAMT+SLC6A8) were unraveled in each brain analyzed $(n=3 ; 2$ females, 1 male). For each combination, mRNA $n^{\circ} 1$ was revealed by ISH coupled to immunohistochemistry for protein $n^{\circ} 2$, followed on adjacent section by ISH detection of mRNA $n^{\circ} 2$ coupled to immunohistochemistry for protein $\mathrm{n}^{\circ} 1$. Particular care was taken to consider identical cells on adjacent sections. All combinations were repeated twice, allowing, for each brain, a total of 4 labeling " 2 by 2 " of each combinations of the 3 genes (12 adjacent sections covering $144 \mu \mathrm{m}$ depth of brain parenchyma). The series of (co-)labeling, distributed among the three rat brains used, were designed to allow the observation of the largest neuronal soma, by the continuous observation of each of the three genes through a depth of $96 \mu \mathrm{m}$ (i.e.: 8 adjacent sections). With each "2 by 2 " combination and for each brain structure, the cell proportions with no expression of genes 1 or 2 , expression of gene 1 only, expression of gene 2 only, or co-expression of genes 1 and 2, were obtained (= values $\mathrm{x}_{\mathrm{i}}$, also defined in Supplementary Tables 2 and 3). Each combination of " 2 by 2 " co-labeling $(n=4)$ gave extremely coherent results (see standard deviations in Supplementary Table 3). Thus, for each gene in each couple of genes, in each of the 10 different brain regions analyzed from 3 different rat brains, mRNA and protein data gave identical proportions: When a specific mRNA was detected on one slice, its respective protein was always detected also in the same cell on the adjacent slice, and no presentation of mRNA without its respective protein occurred. Conversely, when a specific protein was detected on one slice, its respective mRNA was always detected also in the same cell on the adjacent slice, and no presentation of protein without its respective mRNA occurred. Thus, these very coherent data between mRNA (perinuclear region) and protein (considered only in 
the cell soma) validated the gene expression observation in the brain cell soma as truly representative of expression in the whole brain cells.

This allowed then the determination of AGAT, GAMT and SLC6A8 (co-)expression patterns taken "3 by 3" (AGAT+GAMT+SLC6A8 co-expression; see below).

The determination of the "3 by 3" AGAT+GAMT+SLC6A8 co-expression proportions (= values $\mathrm{y}_{\mathrm{j}}$, also defined in Figure 1B and Supplementary Table 2) was obtained using two different approaches:

The first consisted in determining the smallest intervals containing each of the $\mathrm{y}_{1}$ to $\mathrm{y}_{8}$ " 3 by 3" expression proportions. To achieve this, we determined $\mathrm{x}_{\mathrm{i}}$ as the lowest $\mathrm{x}_{1}-\mathrm{x}_{12}$ experimental measure in each brain structure. We chose one of the two $y_{j}$ unknowns giving $x_{i}$ as sum, to express all the other $\mathrm{y}_{1}$ to $\mathrm{y}_{8}$ unknowns, allowing finally the determination of the smallest intervals fitting for $\mathrm{y}_{1}$ to $\mathrm{y}_{8}$ (see their complete determination, illustrated for dentate gyrus, in Supplementary Table 3). These intervals are presented in the left columns of Figure $3 \mathrm{~A}, \mathrm{~B}$ and C (“experimental").

The second was based on the hypothesis, true or not, that AGAT, GAMT and SLC6A8 might be expressed independent of each other in brain cells, both at transcriptional and translational levels. $\mathrm{y}_{1}$ to $\mathrm{y}_{8}$ were calculated, in each brain structure, by developing, based on Figure 1 and Supplementary Table 2, the following equations, exemplified here for $\mathrm{y}_{2}$ (AGAT only) :

1) $y_{2}=x_{2}-y_{6}=x_{2}-\left[y_{6} /\left(y_{2}+y_{6}\right) *\left(y_{2}+y_{6}\right)\right]$

Then, if (and only if) AGAT, GAMT and SLC6A8 genes are expressed independent of each other in the brain, both at transcriptional and translational levels : 
2) $\mathrm{y}_{6} /\left(\mathrm{y}_{2}+\mathrm{y}_{6}\right)=\left(\mathrm{y}_{6}+\mathrm{y}_{8}\right) /\left(\mathrm{y}_{2}+\mathrm{y}_{6}+\mathrm{y}_{5}+\mathrm{y}_{8}\right)$.

After replacement of " $\mathrm{y}_{6} /\left(\mathrm{y}_{2}+\mathrm{y}_{6}\right)$ " in 1) :

3) $\mathrm{y}_{2}=\mathrm{x}_{2}-\left[\left(\mathrm{y}_{6}+\mathrm{y}_{8}\right) /\left(\mathrm{y}_{2}+\mathrm{y}_{6}+\mathrm{y}_{5}+\mathrm{y}_{8}\right) *\left(\mathrm{y}_{2}+\mathrm{y}_{6}\right)\right]=\mathrm{x}_{2}-\left[\mathrm{x}_{8} /\left(\mathrm{x}_{8}+\mathrm{x}_{6}\right) * \mathrm{x}_{2}\right]$.

For each $\mathrm{y}_{\mathrm{j}}, 3$ different (but equivalent) equations can be developed, the 2 equations remaining for $\mathrm{y}_{2}$ being:

4) $y_{2}=x_{6}-y_{5}=x_{6}-\left[x_{10} /\left(x_{10}+x_{9}\right) * x_{6}\right]$,

5) $\mathrm{y}_{2}=\mathrm{x}_{9}-\mathrm{y}_{1}=\mathrm{x}_{9}-\left[\mathrm{x}_{1} /\left(\mathrm{x}_{1}+\mathrm{x}_{2}\right) * \mathrm{x}_{9}\right]$

By analogy, the same calculation procedure was applied to $\mathrm{y}_{1}$ and $\mathrm{y}_{3}$ to $\mathrm{y}_{8}$ (see their complete calcultation, illustrated for dentate gyrus, in Supplementary Table 4). $y_{j}$ values for each brain structure using this second method is presented in the right columns of Figure $3 \mathrm{~A}, \mathrm{~B}$ and $\mathrm{C}$ (“calculated").

\section{Reaggregated brain cell cultures}

Reaggregated brain cell primary cultures were prepared from mechanically dissociated telencephalon of 16-day rat embryos, grown in serum-free, $\mathrm{Cr}$-free, chemically-defined medium (Braissant et al., 2008). These cultures develop with neurons, astrocytes and oligodendrocytes organized in a $3 \mathrm{D}$ network acquiring a tissue-specific pattern resembling that of the in vivo brain, and are therefore considered as organotypic brain cell cultures (Honegger and Monnet-Tschudi, 2001; Cagnon and Braissant, 2007). These cultures express AGAT, GAMT and SLC6A8 in the same cells as in vivo brain and synthesize their own $\mathrm{Cr}$, suggesting that they behave as in vivo CNS for Cr synthesis and transport (Braissant et al., 
2008). Brain cell aggregates were grown for 13 days in vitro (DIV), then exposed for $12 \mathrm{~h}$ or $24 \mathrm{~h}$ to various concentrations of GAA (GAA or ${ }^{13} \mathrm{C}_{2}$-GAA; 200,600 or $1000 \mu \mathrm{M}$ ) and/or $\mathrm{Cr}$

$\left(\mathrm{Cr}\right.$ or ${ }^{13} \mathrm{C}-\mathrm{Cr}$; 200 or $\left.1000 \mu \mathrm{M}\right)$. Aggregates were harvested at DIV13.5 (12h exposure) or DIV14 (24h exposure), washed three times with ice-cold PBS, frozen in liquid nitrogen, and stored at $-80^{\circ} \mathrm{C}$.

\section{Creatine and guanidinoacetate determination, and GAMT activity}

Brain cell aggregates were homogenized in $\mathrm{H}_{2} \mathrm{O}$ at $4^{\circ} \mathrm{C}$ using a FastPrep Cell Disrupter (Qbiogene, France) and centrifuged $\left(10^{\prime} 000 \mathrm{~g}, 5 \mathrm{~min}, 4^{\circ} \mathrm{C}\right)$. The supernatant was used to measure $\mathrm{Cr}$ and GAA by electrospray tandem mass spectrometry, as described in details (Braissant et al., 2008). $\mathrm{D}_{3}$-Cr (CDN Isotopes, Canada) and ${ }^{13} \mathrm{C}_{2}$-GAA (Dr Herman $\mathrm{J}$ ten Brink, Amsterdam, Netherlands) were used as internal standards. $\mathrm{Cr}$ and GAA were purified by micro solid phase extraction (Oasis MCX $\mu$ Elution Plate, Waters, MA USA). Separation of $\mathrm{Cr}$ and GAA was achieved at $30^{\circ} \mathrm{C}$ using an Atlantis HILIC silica $2.1 \times 50 \mathrm{~mm} 3 \mu \mathrm{m}$ (Waters, MA USA). The column effluent was monitored using a Triple Quadrupole TSQ Quantum Discovery (Thermo Scientific, CA USA). The instrument was equipped with an electrospray interface and was controlled by the Xcalibur software (Thermo Scientific, CA USA). Samples were analyzed in positive ionization mode operating in a cone voltage of $4 \mathrm{kV}$. The tandem mass spectrometer was programmed using the selected reaction monitoring mode (SRM) to allow the $\left[\mathrm{MH}^{+}\right]$ions of $\mathrm{Cr}$ and GAA respectively at $\mathrm{m} / z, 132$ and 118 and that of the internal standards $\mathrm{D}_{3}$-Cr and ${ }^{13} \mathrm{C}_{2}$-GAA at $\mathrm{m} / z, 135$ and 120 to pass through the first quadrupole (Q1) and into the collision cell (Q2). The daughter ions for $\mathrm{Cr}$ and GAA are of $m / z \quad 90$ and 76 respectively, and of $m / z 93$ and 78 for $\mathrm{D}_{3}-\mathrm{Cr}$ and ${ }^{13} \mathrm{C}_{2}$-GAA respectively. Calibration curves were computed using the peak area ratio of analytes and internal standards. 
For GAA uptake, brain cell aggregates were incubated for $12 \mathrm{~h}$ or $24 \mathrm{~h}$ with 200 or $600 \mu \mathrm{M}$ GAA. Intracellular GAA was measured as described above using SRM with the transition of $\mathrm{m} / \mathrm{z} 118$ to $\mathrm{m} / \mathrm{z} 76$. For Cr uptake, brain cell aggregates were incubated for $12 \mathrm{~h}$ in presence of $200 \mu \mathrm{M}{ }^{13} \mathrm{C}-\mathrm{Cr}$ (Cambridge Isotope Laboratories, MA USA). Intracellular ${ }^{13} \mathrm{C}-\mathrm{Cr}$ was measured as above using SRM with transition of $\mathrm{m} / \mathrm{z} 133$ to $\mathrm{m} / \mathrm{z}$ 91. The relative abundance of $\mathrm{m} / \mathrm{z} 133$ calculated at a ratio of $3.8 \%$ of endogenous $\mathrm{Cr}$ was deduced from the measured transported ${ }^{13} \mathrm{C}-\mathrm{Cr}$. Uptakes of GAA and ${ }^{13} \mathrm{C}-\mathrm{Cr}(12 \mathrm{~h}$ incubation, $200 \mu \mathrm{M})$ were competed by 5-fold excess (1mM) of $\mathrm{Cr}$ and GAA, respectively.

GAMT activity of brain cell aggregates in vivo was accessed by the synthesis of endogenous ${ }^{13} \mathrm{C}_{2}$-Cr when incubated with ${ }^{13} \mathrm{C}_{2}$-GAA (12h incubation, $200 \mu \mathrm{M}{ }^{13} \mathrm{C}_{2}$-GAA). Newly synthesized ${ }^{13} \mathrm{C}_{2}-\mathrm{Cr}$ was measured using SRM with transition of m/z 134 to m/z 92.

\section{Statistical analysis}

The statistical significance of intracellular GAA and Cr variations (Figure 6) was evaluated by Student's T test. $\mathrm{p}<0.05$ was considered significant. Data were expressed as mean \pm standard deviation. 


\section{Results}

Using ISH coupled to immunohistochemistry, the 3 different "2 by 2 " combinations (AGAT+GAMT; AGAT+SLC6A8; GAMT+SLC6A8) were unraveled on adjacent sections of the rat brain. For each combination, mRNA $n^{\circ} 1$ was revealed by $\mathrm{ISH}$ coupled to immunohistochemistry for protein $\mathrm{n}^{\circ} 2$, followed on adjacent section by ISH detection of mRNA $n^{\circ} 2$ coupled to immunohistochemistry for protein $n^{\circ} 1$. Particular care was taken to consider identical cells on adjacent sections. When a specific mRNA was detected on one slice, its respective protein was always detected also in the same cell on the adjacent slice, and no presentation of mRNA without its respective protein occurred. Conversely, when a specific protein was detected on one slice, its respective mRNA was always detected also in the same cell on the adjacent slice, and no presentation of protein without its respective mRNA occurred.

\section{AGAT, GAMT and SLC6A8 are expressed independent of each other in rat CNS}

Two different approaches were used to determine the "3 by 3" AGAT+GAMT+SLC6A8 coexpression proportions $\left(=\mathrm{y}_{\mathrm{j}}\right.$; as also defined in Figure $1 \mathrm{~B}$ and Supplementary Figure 2$)$ of brain cells. The $1^{\text {st }}$ was the simple estimation of the minimal interval containing each $y_{j}$ proportion based on the direct measure (= cell counting) of the "2 by 2" AGAT, GAMT and SLC6A8 co-expression proportions ( $=x_{i}$; as also defined in Supplementary Figure 2$)$. The $2^{\text {nd }}$ was based on the hypothesis, true or not, that AGAT, GAMT and SLC6A8 might be expressed independent of each other in brain cells, both at the level of transcription and translation. This hypothesis allowed to calculate the " 3 by 3 " expression proportions $\left(\mathrm{y}_{\mathrm{j}}\right)$ from the "2 by 2 " expression proportions $\left(\mathrm{x}_{\mathrm{i}}\right)$. Two strikingly identical expression patterns were found using these two independent approaches (Figure $3 \mathrm{~A}, \mathrm{~B}$ and $\mathrm{C}$ ), in each brain structure analyzed. As the $1^{\text {st }}$ approach is a true measure of the " 3 by 3 " expression proportions, and as 
the $2^{\text {nd }}$ approach is valid only if AGAT, GAMT and SLC6A8 are expressed independent of each other, we conclude that in rat CNS, AGAT, GAMT and SLC6A8 genes are expressed independent of each other, both at the level of transcription and translation.

Four different AGAT, GAMT and SLC6A8 co-expression patterns were found depending of brain structures (Figures 2 and 3). Figures 2, 3, 4 and 5, as well as Supplementary Tables 1, 3 and 4 , show the data from one representative adult rat brain, the same patterns having been obtained in two other adult rat brains.

Cortex, inferior colliculus and cerebellum (molecular layer and deep medial cerebellar nucleus)

In cortex (layer V), 31\% of brain cells were silent for AGAT, GAMT or SLC6A8 (Figures 2BEF and 3A). Cells expressing AGAT, GAMT or SLC6A8 alone were $15 \%, 14 \%$ and 14\% respectively. Cells co-expressing AGAT and GAMT (but not SLC6A8) were 8\%, cells expressing AGAT and SLC6A8 (but not GAMT) were 7\%, and cells co-expressing GAMT and SLC6A8 (but not AGAT) were 8\%. Finally, cells co-expressing AGAT, GAMT and SLC6A 8 were $4 \%$. Thus, in cortex, cells silent for the three genes were $31 \%$, cells equipped for autonomous $\mathrm{Cr}$ synthesis (AGAT+GAMT) were 12\%, and cells equipped for $\mathrm{Cr}$ synthesis from imported GAA (SLC6A8+GAMT) were 12\%. Cells with only SLC6A8 ("users" of Cr, but not participating to its synthesis) were $14 \%$.

Similar expression patterns were found in inferior colliculus as well as in cerebellar molecular layer and deep medial nucleus (Figure 3A). In inferior colliculus, cells silent for the three genes were $33 \%$, cells equipped for autonomous $\mathrm{Cr}$ synthesis were $14 \%$, and cells equipped for Cr synthesis from imported GAA were $16 \%$. Cells with only SLC6A8 were $12 \%$. In molecular layer of cerebellum, cells silent for the three genes were $32 \%$, cells equipped for autonomous $\mathrm{Cr}$ synthesis were $18 \%$, and cells equipped for $\mathrm{Cr}$ synthesis from imported GAA 
were $17 \%$. Cells with only SLC6A8 were 9\%. In deep medial nucleus of cerebellum, cells silent for the three genes were $21 \%$, cells equipped for autonomous $\mathrm{Cr}$ synthesis were $22 \%$, and cells equipped for Cr synthesis from imported GAA were $26 \%$. Cells with only SLC6A8 were $11 \%$.

\section{Hippocampus (CA3 and dentate gyrus granular neurons) and hypothalamus}

Hippocampus (neurons of CA3 layer and dentate gyrus) and ventromedial nucleus of hypothalamus presented similar patterns (Figures $2 \mathrm{CD}$ and 3B). In hippocampal CA3 layer, $40 \%$ of neurons co-expressed AGAT, GAMT and SLC6A8, $20 \%$ being silent for the three genes. $47 \%$ of cells were equipped for autonomous $\mathrm{Cr}$ synthesis, cells equipped for $\mathrm{Cr}$ synthesis from imported GAA were $49 \%$, and cells with SLC6A8 only were $6 \%$. In granular neurons of dentate gyrus, $32 \%$ of cells co-expressed AGAT, GAMT and SLC6A8, 35\% being silent for the three genes. $38 \%$ of cells were equipped for autonomous $\mathrm{Cr}$ synthesis, cells equipped for Cr synthesis from imported GAA were 37\%, and cells with SLC6A8 only were $5 \%$. In hypothalamic ventromedial nucleus, $29 \%$ of cells co-expressed AGAT, GAMT and SLC6A8, 30\% being silent for the three genes. $37 \%$ of cells were equipped for autonomous Cr synthesis, cells equipped for Cr synthesis from imported GAA were 37\%, and cells with SLC6A8 only were $4 \%$.

\section{Purkinje neurons}

$37 \%$ of Purkinje neurons co-expressed AGAT, GAMT and SLC6A8, 9\% only being silent for the three genes. $61 \%$ of Purkinje neurons were equipped for autonomous Cr synthesis, cells equipped for Cr synthesis from imported GAA were 44\%, and cells with SLC6A8 only were $5 \%$ (Figure 3B).

\section{Caudate putamen and pons (parvocellular reticular nucleus)}

Caudate putamen and parvocellular reticular nucleus of pons showed very peculiar patterns 
(Figures 2A and 3C). In caudate putamen, 50\% of cells were silent for AGAT, GAMT or SLC6A8, and 43\% expressed GAMT only. Cells equipped for autonomous Cr synthesis were $1 \%$, cells equipped for $\mathrm{Cr}$ synthesis from imported GAA were $1 \%$, and cells with SLC6A8 only were $2 \%$. In parvocellular reticular nucleus of pons, $44 \%$ of cells were silent for AGAT, GAMT or SLC6A8, and 37\% expressed AGAT only. Cells equipped for autonomous Cr synthesis were $7 \%$, cells equipped for $\mathrm{Cr}$ synthesis from imported GAA were 5\%, and cells with SLC6A8 only were $4 \%$.

\section{Proportions of neurons and astrocytes expressing AGAT, GAMT and SLC6A8 in cortex}

We analyzed within layer V of cortex whether AGAT and GAMT were homogeneously expressed between neurons and glia. This was achieved by ISH for AGAT, GAMT or SLC6A8 mRNAs, coupled to immunohistochemistry for the neuronal marker NeuN or the astrocytic marker GFAP (Figure 4). The abovementioned cell counting method was applied to determine the proportion of specific cell types expressing AGAT, GAMT or SLC6A8 (Figure $5 \mathrm{~A}$ ). We showed that only $22 \%$ of NeuN-positive neurons were positive for AGAT, while $48 \%$ were positive for GAMT. In contrast, $55 \%$ of GFAP-positive astrocytes were positive for AGAT, while only 21\% were positive for GAMT. 27\% of NeuN-positive neurons expressed SLC6A8, while, as expected, no astrocyte was found expressing SLC6A8. As AGAT, GAMT and SLC6A8 are expressed independent of each other (see above and Figure 3), applying the calculation method described in Methods and Supplementary Tables 2 to 4 allowed to reconstitute the differential " 3 by 3 " AGAT+GAMT+SLC6A8 co-expression in cortical neurons and astrocytes (Figure 5B). We show in particular that important proportions of both neurons $(25 \%)$ and astrocytes $(35 \%)$ were silent for the three genes. Based on the 1:0.4 ratio of neurons versus astrocytes in the rat cortex (Nedergaard et al., 2003), we could reconstitute the cumulative proportions of cortical neurons and astrocytes co-expressing AGAT, GAMT and SLC6A8, which fitted remarkably well with the direct measure of expression ranges 
presented in Figure 3A (Figure 5C). The slight variations between both patterns are likely due to other cell types present in lower proportions within cortex (oligodendrocytes, microglia), which were not evaluated here.

\section{Brains cells take up guanidinoacetate and convert it to creatine}

As most rat brain structures showed a high proportion of cellular dissociation between AGAT- and GAMT-expressing cells, we hypothesized that brain cells were able to import GAA, and convert it to $\mathrm{Cr}$. Using rat brain cell primary cultures in aggregates, we first demonstrated by tandem mass spectrometry that brain cells can import GAA (Figure 6A). Exposure up to $200 \mu \mathrm{M}$ GAA for $12 \mathrm{~h}$ did not disturb the endogenous $\mathrm{Cr}$ synthesis pathway, which occurs in this system as in CNS in vivo (Braissant et al., 2008); a higher GAA concentration $(600 \mu \mathrm{M})$ was toxic to brain cells, as shown by the $30 \%$ decrease in intracellular $\mathrm{Cr}$ (Figure 6A), as well as by axonal growth impairment and induction of apoptosis (data not shown). 24h GAA exposure had the same effects (data not shown). We further showed that imported GAA could be converted to $\mathrm{Cr}$, by exposing brain cell aggregates to ${ }^{13} \mathrm{C}$ stable isotope-labelled ${ }^{13} \mathrm{C}_{2}$-GAA, and measuring intracellular ${ }^{13} \mathrm{C}_{2}$-Cr. After $12 \mathrm{~h}$ exposure to $200 \mu \mathrm{M}{ }^{13} \mathrm{C}_{2}$-GAA, $29 \%$ of imported ${ }^{13} \mathrm{C}_{2}$-GAA was converted to ${ }^{13} \mathrm{C}_{2}$ - $\mathrm{Cr}$ (Figure 6B). Finally, we showed that $1000 \mu \mathrm{M}$ Cr completely competed GAA uptake by brain cells ( $200 \mu \mathrm{M}$ GAA exposure), with the same efficiency as $1000 \mu \mathrm{M}$ GAA competed Cr uptake $\left(200 \mu \mathrm{M}{ }^{13} \mathrm{C}-\mathrm{Cr}\right.$ exposure, to avoid influence of the endogenous $\mathrm{Cr}$ synthesis pathway) (Figure 6C). 


\section{Discussion}

\section{Brain AGAT, GAMT and SLC6A8 are expressed independent of each other}

This work demonstrates that AGAT, GAMT and SLC6A8 are expressed independent of each other in CNS, at the level of transcription and translation. $\mathrm{Cr}$ exerts a negative pretranslational feedback on AGAT regulation in kidney (McGuire et al., 1984). Brain appears to behave differently, where Cr rather alters AGAT enzymatic activity (Braissant et al., 2008). Human muscle behave similarly, where $\mathrm{Cr}$ does not influence SLC6A8 expression (Tarnopolsky et al., 2003). Thus, brain AGAT, GAMT and SLC6A8 expression does not seem influenced by their substrate or reaction products, probably allowing CNS to be permanently equipped with $\mathrm{Cr}$ synthesis and transport machineries, something crucial knowing that $\mathrm{Cr}$ is essential in CNS development and functions (Braissant \& Henry, 2008; Andres et al., 2008).

\section{Dissociation of AGAT and GAMT, and GAA uptake by brain cells: Relevance to Cr deficiency syndromes}

Brain Cr was thought to come principally from periphery through BBB (Wyss \& KaddurahDaouk, 2000). However, mammalian CNS synthesizes Cr and express AGAT and GAMT in every cell types (Pisano et al., 1963; Braissant et al., 2001a; Schmidt et al., 2004; Tachikawa et al., 2004). SLC6A8 is expressed in CNS, but only by neurons and oligodendrocytes. The SLC6A8 absence from astrocytes (particularly astrocyte feet lining MCEC; Braissant et al., 2001a; Ohtsuki et al., 2002; Tachikawa et al., 2004) made us suggest that BBB has a limited permeability for $\mathrm{Cr}$, and that CNS depends more on autonomous $\mathrm{Cr}$ synthesis than on supply from periphery (Braissant et al., 2007; Braissant \& Henry, 2008). 
Brain autonomous Cr synthesis seems contradictory with in vivo characteristics of SLC6A8 deficiency, which, despite normal CNS expression of AGAT and GAMT, shows no, or very low levels of, brain Cr by MRS, as in AGAT and GAMT deficiencies. We hypothesized that this apparent contradiction might be explained by brain patterns of AGAT, GAMT and SLC6A8, which might be expressed in a dissociated way (Braissant and Henry, 2008).

This work demonstrates that in many brain structures, including these usually observed by MRS, cells fully equipped for Cr synthesis (co-expressing AGAT+GAMT) are $<20 \%$ (cortex: $12 \%$, striatum: $1 \%$ ), and that a higher proportion of cells expresses AGAT without GAMT, or GAMT without AGAT. This suggested that for $\mathrm{Cr}$ synthesis to occur, GAA must be transported from AGAT- to GAMT-expressing cells. If GAA is transported by SLC6A8 (see below), it would explain the absence of Cr measured by MRS in CNS of SLC6A8-deficient patients. This recently-proposed model (Braissant \& Henry, 2008) is also supported in vivo by the attempt to treat SLC6A8-deficient patients with arginine to stimulate replenishment of their cerebral $\mathrm{Cr}$ pool by brain endogenous synthesis, which failed to increase CNS Cr (Fons et al., 2008). Thus, according to the above-mentioned hypothesis, in human brain also, GAA must be transported from AGAT- to GAMT-expressing cells, through SLC6A8, for Cr synthesis to occur.

Whilst in most regions of AGAT- and GAMT-deficient brain, the MRS measure of Cr should show an absence or strong decrease of $\mathrm{Cr}$ (partly due to the lack of brain autonomous $\mathrm{Cr}$ synthesis), the situation may be more contrasted in SLC6A8 deficiency. Indeed, the MRS Cr measure is usually performed in cortical areas and basal ganglia (striatum), where SLC6A8deficient patients present an absence or strong decrease of $\mathrm{Cr}$ (DeGrauw et al., 2002) (excepted for females heterozygous for SLC6A8 mutation, who usually present a milder 
cerebral Cr deficiency, as SLC6A8 deficiency is an X-linked disorder). If AGAT, GAMT and SLC6A8 patterns, as described here in rat CNS, are also true in human, a normal or only attenuated $\mathrm{Cr}$ peak should be detected in brain regions of SLC6A8-deficient patients presenting high proportions of cells co-expressing AGAT+GAMT, like hippocampus, hypothalamus or Purkinje cells.

The striking patterns found for AGAT in pons and GAMT in caudate putamen are difficult to interprete. However, the GAMT-only expression of caudate putamen may fit with GAMT deficiency, which impairs striatum development (Von Figura et al., 2001).

\section{GAA uptake by brain cells, and conversion to $\mathrm{Cr}$}

GAA competes for Cr uptake by SLC6A8 (Ohtsuki et al., 2002). Our work brings the first evidence that cells of brain parenchyma (neurons, astrocytes, oligodendrocytes) can take up GAA. GAA uptake was completely competed by 5-fold excess Cr, as efficiently as Cr uptake was competed by 5 -fold excess GAA. This strongly suggests that GAA is taken up by brain cells through the same transporter as Cr: SLC6A8. This is in good agreement with SLC6A8 overexpression studies in HEK293 cells and Xenopus oocytes (Tachikawa et al., 2008). Finally, using ${ }^{13} \mathrm{C}_{2}$-GAA, our work is the first to demonstrate that GAA taken-up by brain cells is readily converted to $\mathrm{Cr}$, in line with our hypothesis that for $\mathrm{Cr}$ synthesis to occur in CNS, GAA must be transported from AGAT- to GAMT-expressing cells. The low proportion of GAA conversion to $\mathrm{Cr}(29 \%)$ was due to the diluting effect of endogenous $\mathrm{Cr}$ synthesis pathway. One important question remaining to elucidate is how GAA can leave AGATexpressing cells to be imported by GAMT-expressing cells through SLC6A8.

A recent work demonstrated GAA uptake by TR-CSFB cells (blood-CSF barrier model) and 
isolated choroid plexus in vitro, probably by SLC6A8, but concluded that due to GAA:Cr ratio in CSF $(1: 1000 ; 0.015-0.560 \mu \mathrm{M}$ versus $17-90 \mu \mathrm{M}$ in human; Braissant and Henry, 2008), SLC6A8 was unlikely to transport GAA in choroid plexus in vivo (Tachikawa et al., 2008). Cr and GAA concentrations are much higher in brain parenchyma $(5-6 \mathrm{mM}$ and $0.9-1.6 \mathrm{mM}$ in human, respectively), but nothing is known on their concentrations in extracellular fluid. In rat brain parenchyma, Cr was measured at $8.5 \mathrm{mM}$ (Renema et al., 2003), and we measured GAA at levels 5-10 fold lower than $\mathrm{Cr}$ in rat brain cell organotypic cultures (Braissant et al., 2008; and this study). We may thus extrapolate levels of GAA in rat brain parenchyma at $0.85-1.7 \mathrm{mM}$, comparable to human. $200 \mu \mathrm{M}$ GAA, as used in this study, may thus be relevant in CNS extracellular fluid, at least locally, in vicinity of GAA transfer from AGAT- to GAMT-expressing cells.

\section{AGAT and GAMT dissociation, as well as $\mathrm{Cr}$ and GAA uptake in CNS: A role for neuromodulation?}

Dissociation of AGAT and GAMT activities between different brain cells may appear expensive for CNS in terms of both the energy and machinery needed to transfer GAA, and GAA toxicity to neurons if released in the extracellular space at too high concentrations. $\mathrm{Cr}$ is exocytotically released from central neurons (Almeida et al., 2006) and acts as partial agonist on central $\mathrm{GABA}_{\mathrm{A}}$ post-synaptic receptors (Koga et al., 2005), suggesting a role of cotransmitter modulating postsynaptic GABA receptors. On the other hand, GAA can activate $\mathrm{GABA}_{\mathrm{A}}$ receptors in cortical and cerebellar neurons (Neu et al., 2002; Cupello et al., 2008). In cortex in particular, GAA can activate $\mathrm{GABA}_{\mathrm{A}}$ receptors at concentrations compatible with its levels in CNS extracelllar fluid (see above; and Neu et al., 2002; Braissant and Henry, 2008). Thus, both $\mathrm{Cr}$ and GAA can act as neuromodulators. Keeping AGAT and GAMT expression separated in different brain cells might thus facilitate the fine tuning of the 
respective synthesis of GAA and $\mathrm{Cr}$ for their specific roles of neuromodulation, while the efficient uptake of $\mathrm{Cr}$ and GAA by brain cells might be essential for keeping their extracellular concentrations in low ranges, to allow neuromodulation ( $\mathrm{Cr}$ and GAA) while avoiding toxic effects of GAA.

\section{Fine tuning versus high flux of $\mathrm{Cr}$ synthesis and transport in the brain}

Two strikingly coherent main expression patterns are found in the different brain structures. In $1^{\text {st }}$ one, present in most brain regions, high proportions of cells do not express either AGAT, GAMT or SLC6A8 (20-50\%), the proportion of cells expressing SLC6A8 only (Cr "users") remains below 15\%, while AGAT and GAMT are not co-expressed. These structures, distributed throughout the whole CNS, may need the dissociation between AGAT and GAMT expression, as well as the low proportion of cells expressing SLC6A8, for the fine tuning of GAA and $\mathrm{Cr}$ synthesis described above, and their respective roles in neuromodulation.

In $2^{\text {nd }}$ one, specific structures (hippocampus, Purkinje neurons) present high proportions of cells co-expressing AGAT+GAMT (40-60\%), and high proportions of cells expressing SLC6A8 (45-65\%). It suggests that these neuronal layers permanently need high Cr levels, in line with their high creatine kinase activity (Wallimann \& Hemmer, 1994; Kaldis et al., 1996).

\section{Neuronal versus glial synthesis of creatine}

While GAMT is expressed by rat neurons and glia (Braissant et al., 2001a), data showing GAMT predominantly (but not exclusively) in mouse glia (Schmidt et al., 2004; Tachikawa et al., 2004) suggested that $\mathrm{Cr}$ synthesis final step may principally be glial. Brain mixed-cell or 
astrocyte primary cultures synthesize Cr (Dringen et al., 1998; Braissant et al., 2008), but we also showed that neuron-enriched primary cultures synthesize $\mathrm{Cr}$ (Braissant et al., 2002). This study demonstrates that depending on brain structure, $\mathrm{Cr}$ synthesis may occur both in neurons and glia. In cortex, $48 \%$ of NeuN-positive neurons and $21 \%$ of GFAP-positive astrocytes expressed GAMT. CA3, dentate gyrus and Purkinje neurons were 50\%-70\% to express GAMT. Both neurons and astrocytes presented every possibility of AGAT, GAMT and SLC6A8 co-expression patterns (apart of SLC6A8 absence from astrocytes), and both neurons and astrocytes could be silent for the three genes. It is emphasized that oligodendrocytes, not evaluated in this study, highly express GAMT (Schmidt et al., 2004; Tachikawa et al., 2004; Braissant et al., 2008), and may be high Cr producers. It remains also to elucidate how $\mathrm{Cr}$ can leave "Cr producers" to be taken up by "Cr users" through SLC6A8.

\section{Conclusion}

We show that in numerous rat brain structures, including cortex and caudate putamen, AGAT and GAMT are expressed in a dissociated way, suggesting GAA transport from AGAT- to GAMT-expressing cells to allow $\mathrm{Cr}$ synthesis. Accordingly, this work is the first to demonstrate that brain cells can take up GAA probably through SLC6A8, and convert it to Cr. Taken together, our results explain the absence of $\mathrm{Cr}$ in the brain of SLC6A8-deficient patients, despite normal AGAT and GAMT expression.

\section{Acknowledgments}

We thank Marc Loup for excellent technical work. This work was supported by the Swiss National Science Foundation (grants $\mathrm{n}^{\circ} 3100 \mathrm{~A} 0-100778$ and 3100A0-116859). 


\section{References}

Almeida, L.S., Salomons, G.S., Hogenboom, F., Jakobs, C., Schoffelmeer, A.N., 2006. Exocytotic release of creatine in rat brain. Synapse 60, 118-123.

Andres, R.H., Ducray, A.D., Schlattner, U., Wallimann, T., Widmer, H.R., 2008. Functions and effects of creatine in the central nervous system. Brain. Res. Bull. 76, 329-343.

Braissant, O., 2004. Measurement of nitric oxide-related enzymes in the brain by in situ hybridization. Methods Mol. Biol. 279, 113-124.

Braissant, O., Henry, H., 2008. AGAT, GAMT and SLC6A8 distribution in the central nervous system, in relation to creatine deficiency syndromes: A review. J. Inher. Metab. Dis. $31,230-239$.

Braissant, O., Henry, H., Loup, M., Eilers, B., Bachmann, C., 2001a. Endogenous synthesis and transport of creatine in the rat brain: an in situ hybridization study. Mol. Brain Res. $86,193-201$.

Braissant, O., Gotoh, T., Loup, M., Mori, M., Bachmann, C., 2001b. Differential expression of the cationic amino acid transporter 2(B) in the adult rat brain. Mol. Brain Res. 91, 189195.

Braissant, O., Henry, H., Villard, A.M., Zurich, M.G., Loup, M., Eilers, B., Parlascino, G., Matter, E., Boulat, O., Honegger, P., Bachmann, C., 2002. Ammonium-induced impairment of axonal growth is prevented through glial creatine. J. Neurosci. 22, 98109820. 
Braissant, O., Henry, H., Villard, A.M., Speer, O., Wallimann, T., Bachmann, C., 2005. Creatine synthesis and transport during rat embryogenesis: Spatiotemporal expression of AGAT, GAMT and CT1. BMC Dev. Biol. 5, 9.

Braissant, O., Bachmann, C., Henry, H., 2007. Expression and function of AGAT, GAMT and CT1 in the mammalian brain. Subcell. Biochem. 46, 67-81.

Braissant, O., Cagnon, L., Monnet-Tschudi, F., Speer, O., Wallimann, T., Honegger, P., Henry, H., 2008. Ammonium alters creatine transport and synthesis in a 3D-culture of developing brain cells, resulting in secondary cerebral creatine deficiency. Eur. J. Neurosci. 27, 1673-1685.

Cagnon, L., Braissant, O., 2007. Hyperammonemia-induced toxicity for the developing central nervous system. Brain Res. Rev. 56, 183-197.

Cupello, A., Balestrino, M., Gatta, E., Pellistri, F., Siano, S., Robello, M., 2008. Activation of cerebellar granule cells GABA(A) receptors by guanidinoacetate. Neuroscience 152, 6569.

DeGrauw, T.J., Salomons, G.S., Cecil, K.M., Chuck, G., Newmeyer, A., Schapiro, M.B., Jakobs, C., 2002. Congenital creatine transporter deficiency. Neuropediatrics 33, 232-238.

Dringen, R., Verleysdonk, S., Hamprecht, B., Willker, W., Leibfritz, D., Brand, A., 1998. Metabolism of glycine in primary astroglial cells: synthesis of creatine, serine, and glutathione. J. Neurochem. 70, 835-840.

Fons, C., Sempere, A., Arias, A., López-Sala, A., Póo, P., Pineda, M., Mas, A., Vilaseca, M.A., Salomons, G.S., Ribes, A., Artuch, R., Campistol, J., 2008. Arginine 
supplementation in four patients with X-linked creatine transporter defect. J. Inherit. Metab. Dis. 31, 724-728.

Honegger, P., Monnet-Tschudi, F., 2001. Aggregating neural cell culture. In: Fedoroff, S., Richardson, A., (Eds.). Protocols for neural cell culture. Humana Press Inc., Totowa NJ, pp. 199-218.

Item, C.B., Stöckler-Ipsiroglu, S., Stromberger, C., Mühl, A., Alessandri, M.G., Bianchi, M.C., Tosetti, M., Fornai, F., Cioni, G., 2001. Arginine:glycine amidinotransferase deficiency: the third inborn error of creatine metabolism in humans. Am. J. Hum. Genet. $69,1127-1133$.

Kaldis, P., Hemmer, W., Zanolla, E., Holtzman, D., Wallimann, T., 1996. 'Hot spots' of creatine kinase localization in brain: cerebellum, hippocampus and choroid plexus. Dev. Neurosci. 18, 542-554.

Koga, Y., Takahashi, H., Oikawa, D., Tachibana, T., Denbow, D.M., Furuse, M., 2005. Brain creatine functions to attenuate acute stress responses through GABAnergic system in chicks. Neuroscience 132, 65-71.

McGuire, D.M., Gross, M.D., Van Pilsum, J.F., Towle, H.C., 1984. Repression of rat kidney L-arginine:glycine amidinotransferase synthesis by creatine at a pretranslational level. J. Biol. Chem. 259, 12034-12038.

Nedergaard, M., Ransom, B., Goldman, S.A., 2003. New roles for astrocytes: Redefining the functional architecture of the brain. Trends Neurosci. 26, 523-530. 
Neu, A., Neuhoff, H., Trube, G., Fehr, S., Ullrich, K., Roeper, J., Isbrandt, D., 2002. Activation of GABA(A) receptors by guanidinoacetate: a novel pathophysiological mechanism. Neurobiol. Dis. 11, 298-307.

Ohtsuki, S., Tachikawa, M., Takanaga, H., Shimizu, H., Watanabe, M., Hosoya, K., Terasaki, T., 2002. The blood-brain barrier creatine transporter is a major pathway for supplying creatine to the brain. J. Cereb. Blood Flow Metab. 22, 1327-1335.

Perasso, L., Cupello, A., Lunardi, G.L., Principato, C., Gandolfo, C., Balestrino, M., 2003. Kinetics of creatine in blood and brain after intraperitoneal injection in the rat. Brain Res. $974,37-42$.

Pisano, J.J., Abraham, D., Udenfriend, S., 1963. Biosynthesis and disposition of $\gamma$ guanidinobutyric acid in mammalian tissues. Arch. Biochem. Biophys. 100, 323-329.

Renema, W.K., Schmidt, A., van Asten, J.J., Oerlemans, F., Ullrich, K., Wieringa, B., Isbrandt, D., Heerschap, A., 2003. MR spectroscopy of muscle and brain in guanidinoacetate methyltransferase (GAMT)-deficient mice: validation of an animal model to study creatine deficiency. Magn. Reson. Med. 50, 936-943.

Salomons, G.S., van Dooren, S.J., Verhoeven, N.M., Cecil, K.M., Ball, W.S., DeGrauw, T.J., Jakobs, C., 2001. X-linked creatine-transporter gene (SLC6A8) defect: a new creatinedeficiency syndrome. Am. J. Hum. Genet. 68, 1497-1500.

Schmidt, A., Marescau, B., Boehm, E.A., Renema, W.K., Peco, R., Das, A., Steinfeld, R., Chan, S., Wallis, J., Davidoff, M., Ullrich, K., Waldschütz, R., Heerschap, A., De Deyn, P.P., Neubauer, S., Isbrandt, D., 2004. Severely altered guanidino compound levels, disturbed body weight homeostasis and impaired fertility in a mouse model of 
guanidinoacetate N-methyltransferase (GAMT) deficiency. Hum. Mol. Genet. 13, 905921.

Schulze, A., Hess, T., Wevers, R., Mayatepek, E., Bachert, P., Marescau, B., Knopp, M.V., De Deyn, P.P., Bremer, H.J., Rating, D., 1997. Creatine deficiency syndrome caused by guanidinoacetate methyltransferase deficiency: diagnostic tools for a new inborn error of metabolism. J. Pediatr. 131, 626-631.

Schulze, A., Battini, R., 2007. Pre-symptomatic treatment of creatine biosynthesis defects. Subcell. Biochem. 46, 167-181.

Stöckler, S., Holzbach, U., Hanefeld, F., Marquardt, I., Helms, G., Requart, M., Hänicke, W., Frahm, J., 1994. Creatine deficiency in the brain: a new, treatable inborn error of metabolism. Pediatr. Res. 36, 409-413.

Stöckler, S., Schutz, P.W., Salomons, G.S., 2007. Cerebral creatine deficiency syndromes: Clinical aspects, treatment and pathophysiology. Subcell. Biochem. 46, 149-166.

Tachikawa, M., Fukaya, M., Terasaki, T., Ohtsuki, S., Watanabe, M., 2004. Distinct cellular expressions of creatine synthetic enzyme GAMT and creatine kinases uCK-Mi and CK-B suggest a novel neuron-glial relationship for brain energy homeostasis. Eur. J. Neurosci. 20, 144-160.

Tachikawa, M., Fujinawa, J., Takahashi, M., Kasai, Y., Fukaya, M., Sakai, K., Yamazaki, M., Tomi, M., Watanabe, M., Sakimura, K., Terasaki, T., Hosoya, K., 2008. Expression and possible role of creatine transporter in the brain and at the blood-cerebrospinal fluid barrier as a transporting protein of guanidinoacetate, an endogenous convulsant. J. Neurochem. 107, 768-778. 
Tarnopolsky, M., Parise, G., Fu, M.H., Brose, A., Parshad, A., Speer, O., Wallimann, T.,2003. Acute and moderate-term creatine monohydrate supplementation does not affect creatine transporter mRNA or protein content in either young or elderly humans. Mol. Cell. Biochem. 244, 159-166.

Von Figura, K., Hanefeld, F., Isbrandt, D., Stöckler-Ipsiroglu, S., 2001. Guanidinoacetate methyltransferase deficiency. In: Scriver, C.R., Beaudet, A.L., Sly, W.S., Valle, D. (Eds.). The metabolic and molecular bases of inherited disease. McGraw-Hill, New York, pp. 1897-908.

Wallimann, T., Hemmer, W., 1994. Creatine kinase in non-muscle tissues and cells. Mol. Cell. Biochem. 133-134, 193-220.

Wyss, M., Kaddurah-Daouk, R., 2000. Creatine and creatinine metabolism. Physiol. Rev. 80, 1107-1213. 


\section{Figure legends}

\section{Figure 1: Rat brain structures analyzed for AGAT, GAMT and SLC6A8 co-expression.}

A: 10 different structures of the rat brain were analyzed: Cortex (layer V, Cx); caudate putamen (CP); hippocampus (CA3 and dentate gyrus neurons, DG); hypothalamus (ventromedial nucleus, VMH); inferior colliculus (IC); pons (parvocellular reticular nucleus, PCRt); cerebellum (molecular layer, Mol; Purkinje neurons, Pur; and deep medial nucleus, Med) (sagittal view of rat brain adapted from http://www.brain-map.org; lateral level for rat brain: $1.20 \mathrm{~mm}$ ). B: The proportions of cells (co-)expressing AGAT alone (y2), GAMT alone (y3), SLC6A8 alone (y4), AGAT + GAMT (y5), AGAT + SLC6A8 (y6), GAMT + SLC6A8 $(\mathbf{y} 7)$, AGAT + GAMT + SLC6A8 $(\mathbf{y 8})$, or none $(\mathbf{y 1})$, were determined in each brain structures (see also Supplementary Tables 2, 3 and 4).

Figure 2: Co-expression of AGAT, GAMT and SLC6A8 in the rat brain. In situ hybridization (mRNA, blue signal) coupled to immunohistochemistry (protein, red signal), showing "2 by 2" co-expression of (A) AGAT mRNA and GAMT protein in pons, (B) GAMT mRNA and AGAT protein in layer V of cortex, (C) AGAT mRNA and SLC6A8 protein in hypothalamus, (D) SLC6A8 mRNA and AGAT protein in CA3 neurons, (E) GAMT mRNA and SLC6A8 protein in layer V of cortex, and (F) SLC6A8 mRNA and GAMT protein in layer V of cortex. Examples of cells without any labeling are indicated by empty arrows; examples of cells with gene 1 mRNA expression only are indicated by blue arrows; examples of cells with gene 2 protein expression only are indicated by red arrows; examples of cells with co-labeling for gene $1 \mathrm{mRNA}$ and gene 2 protein are indicated by purple arrows. Bar: $50 \mu \mathrm{m}$. 
Figure 3: Co-expression of AGAT, GAMT and SLC6A8 in the different structures of the rat brain. A: cortex, inferior colliculus and cerebellum (molecular layer and deep medial nucleus). B: hippocampus (CA3 and dentate gyrus), hypothalamus (ventromedial nucleus) and cerebellum (Purkinje neurons). C: caudate putamen and pons (parvoreticular nucleus). The percentage of cells (co-)expressing AGAT alone, GAMT alone, SLC6A8 alone, AGAT+GAMT, AGAT+SLC6A8, GAMT+SLC6A8, AGAT+GAMT+SLC6A8, or none, is indicated, for both methods used (experimental and calculated) to estimate these proportions (see also Figure 2 for an illustration of the co-labeling used). For the experimental measure of co-expression proportions (left column), the ranges between minimal and maximal proportions are represented (open white rectangle). For the calculated proportions (right column), means \pm standard deviations $(n=3)$ are represented.

Figure 4: Expression of AGAT, GAMT and SLC6A8 in cortical neurons and astrocytes. In situ hybridization for AGAT (A,D), GAMT (B,E) and SLC6A8 (C,F) mRNAs (blue signal), coupled to immunohistochemistry for neuronal (NeuN; A-C) and astrocytic (GFAP; D-F) markers respectively (red signal). Examples of neurons and astrocytes without colabelling for AGAT, GAMT or SLC6A8 are indicated by red arrows, while examples of neurons and astrocytes with co-labelling for AGAT, GAMT or SLC6A8 are indicated by purple arrows. Bar: $50 \mu \mathrm{m}$.

Figure 5: Proportions of neurons and astrocytes expressing AGAT, GAMT and SLC6A8, respectively, within layer $V$ of cortex. Cell counting as described in Material and Methods, from co-labeling experiments as shown in Figure 4 (ISH for AGAT, GAMT or SLC6A8, coupled to immunohistochemistry for NeuN or GFAP to identify neurons and 
astrocytes, respectively). Data from a representative adult rat cortex; 6 adjacent sections observed for each co-labeling experiment; total number of NeuN-positive neurons: 441; total number of GFAP-positive astrocytes: 337. The cell percentages are based on the cumulative counting of the 6 adjacent sections, for each co-labeling experiment. A: proportions of cortical neurons, respectively astrocytes, expressing AGAT, GAMT or SLC6A8; B: reconstitution of the "3 by 3" AGAT, GAMT and SLC6A8 expression pattern within cortical neurons and astrocytes; C: reconstitution of the cumulative, neuronal and astrocytic, "3 by 3 " AGAT, GAMT and SLC6A8 expression pattern, based on the ratio of 1 neuron per 0.4 astrocyte (Nedergaard et al., 2003). Measured ranges between minimal and maximal proportions (taken from Figure 3A) are shown in white rectangles, for comparison.

Figure 6: Uptake of guanidinoacetate by brain cells, and conversion to creatine. Measure of intracellular GAA and $\mathrm{Cr}$ within brain cell 3D cultures (DIV13) by tandem mass spectrometry, after $12 \mathrm{~h}$ of exposure to GAA (GAA or ${ }^{13} \mathrm{C}_{2}$-GAA) and/or $\mathrm{Cr}\left(\mathrm{Cr}\right.$ or $\left.{ }^{13} \mathrm{C}-\mathrm{Cr}\right)$. A: GAA Uptake by brain cells, and influence on endogenous Cr synthesis pathway. Cultures exposed for $12 \mathrm{~h}$ to 200 and $600 \mu \mathrm{M}$ GAA, respectively, and measure of intracellular GAA and Cr. B: Conversion of GAA taken up by brain cells to Cr. Cultures exposed for $12 \mathrm{~h}$ to $200 \mu \mathrm{M}$ ${ }^{13} \mathrm{C}_{2}$-GAA, and measure of intracellular ${ }^{13} \mathrm{C}_{2}$-GAA and ${ }^{13} \mathrm{C}_{2}$-Cr. C: Competition of GAA uptake by $\mathrm{Cr}$, respectively of $\mathrm{Cr}$ uptake by GAA, in brain cells. Cultures exposed $12 \mathrm{~h}$ to $200 \mu \mathrm{M}$ GAA $( \pm$ competition with $1000 \mu \mathrm{M} \mathrm{Cr})$, respectively $200 \mu \mathrm{M}{ }^{13} \mathrm{C}-\mathrm{Cr}( \pm$ competition with $1000 \mu \mathrm{M}$ GAA), and measure of intracellular GAA, respectively ${ }^{13} \mathrm{C}-\mathrm{Cr}$. A, B and $\mathbf{C}$ show representative experiments, with mean \pm standard deviations for each point of measure. Significant increase in GAA, respectively decrease in $\mathrm{Cr}(\mathbf{A})$ are indicated, as compared to control conditions $(200 \mu \mathrm{M}$ GAA), respectively to control conditions and $200 \mu \mathrm{M}$ GAA (600 $\mu$ M GAA). Student's $t$ test; $\mathrm{n}=3$; NS: not significant; **: $\mathrm{p}<0.01 ; * * *: \mathrm{p}<0.001)$. 

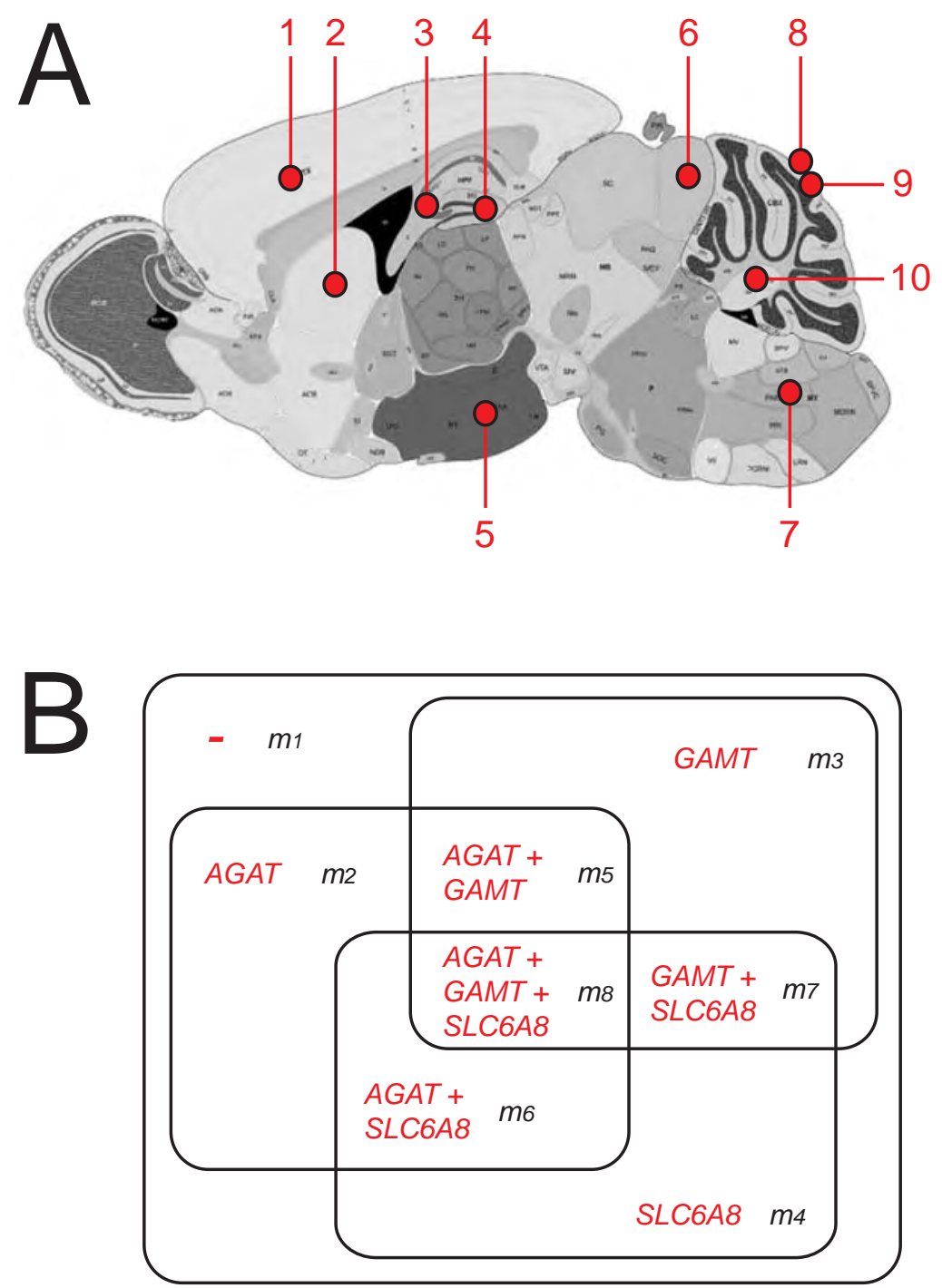

Braissant et al., Figure 1 

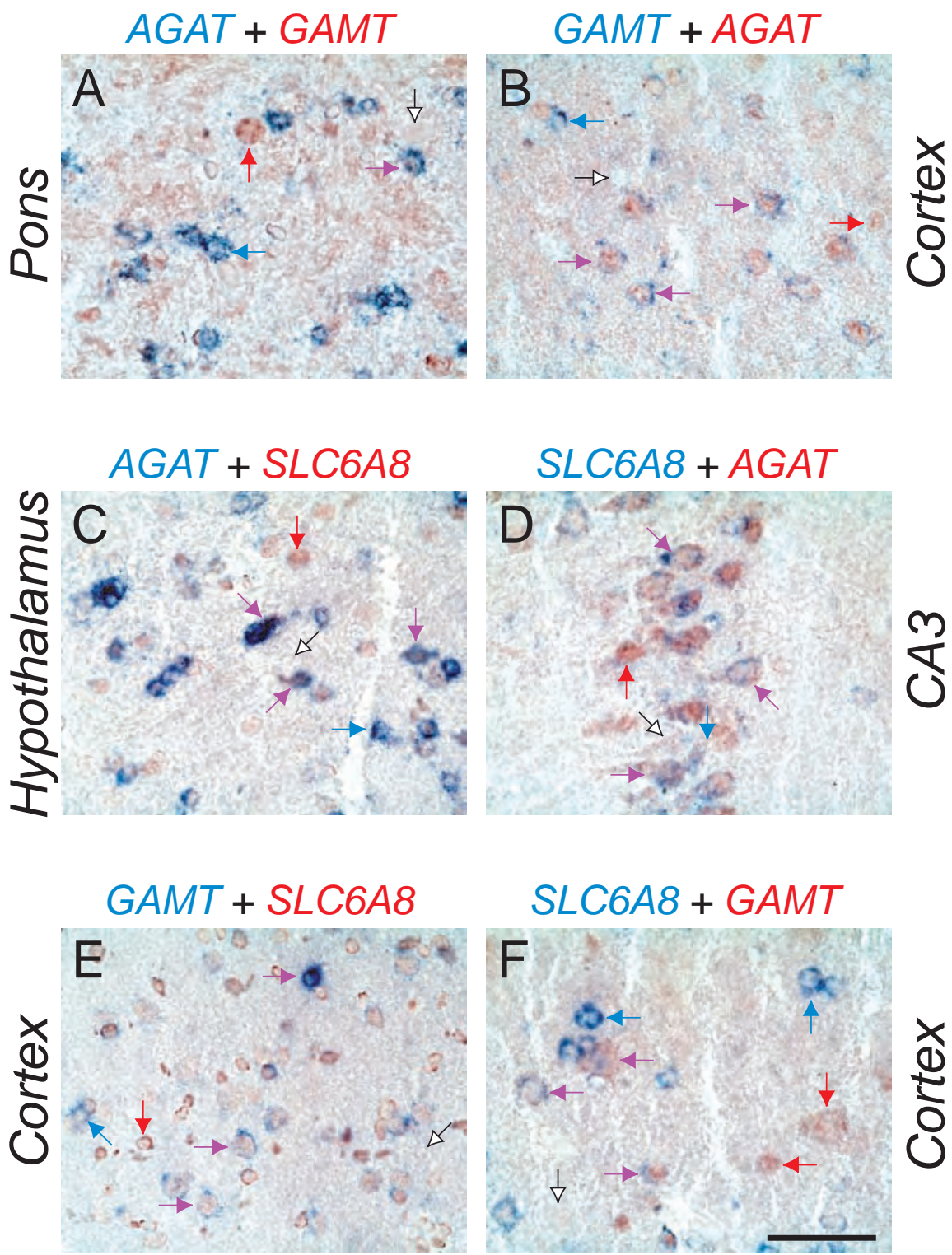


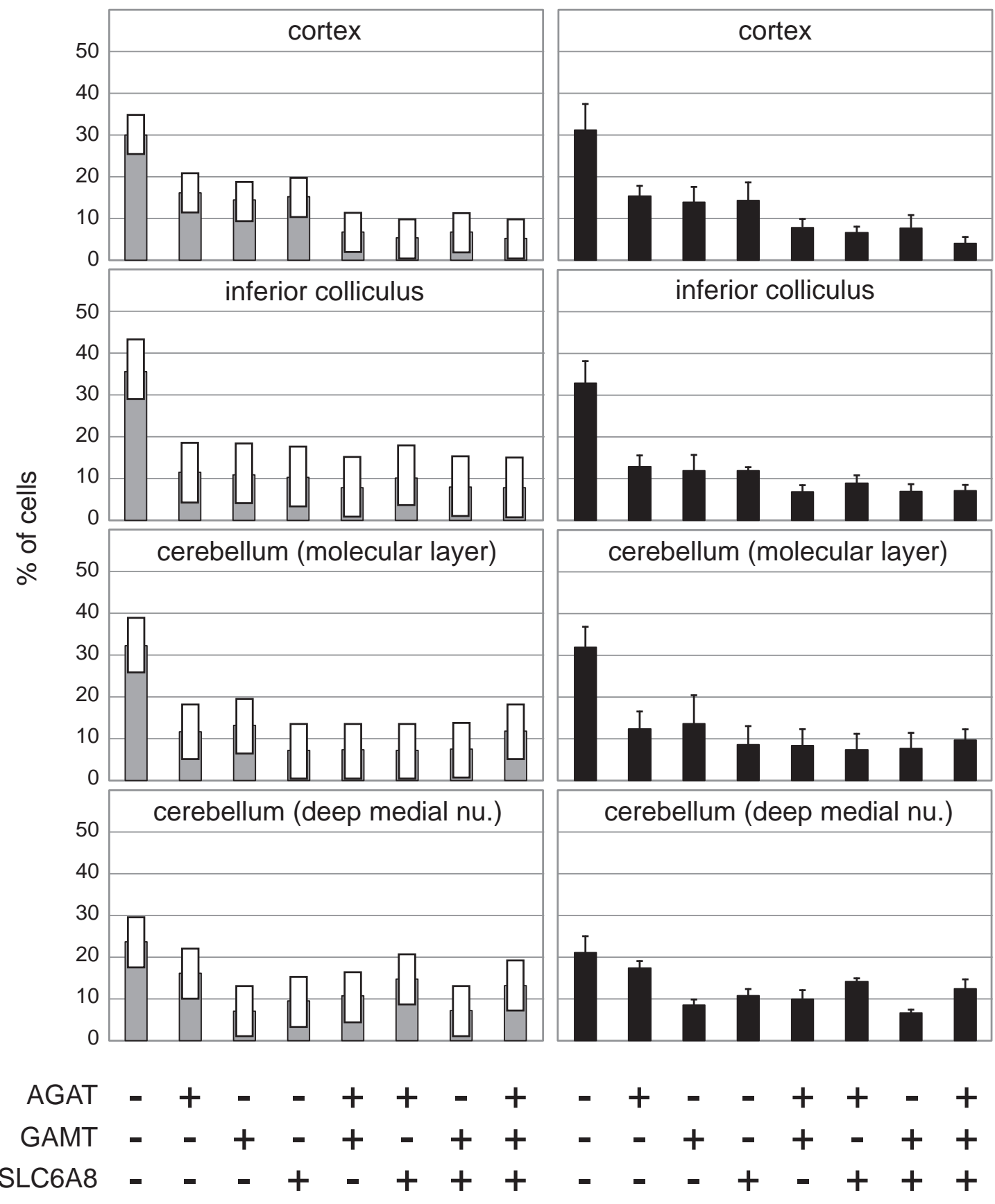




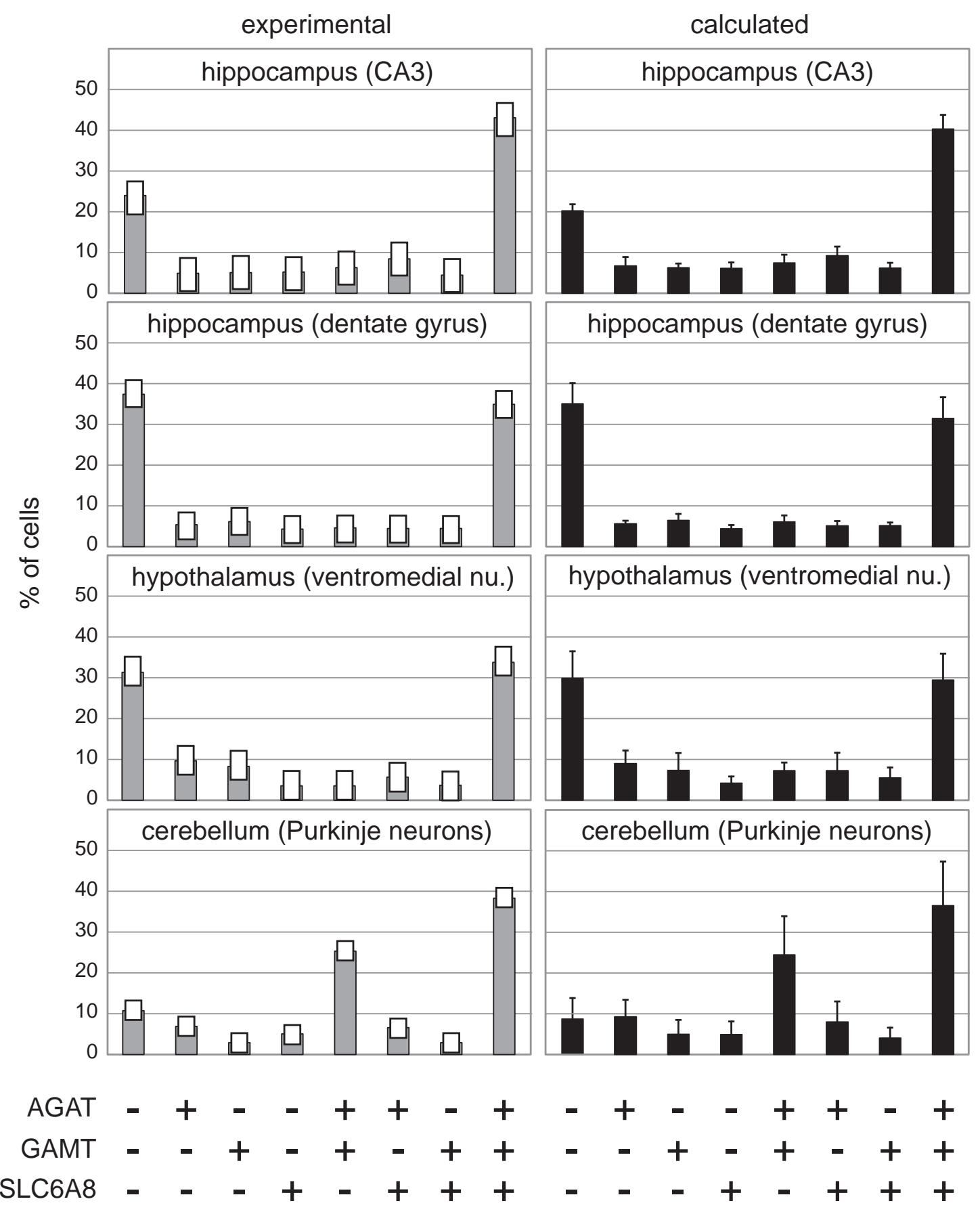




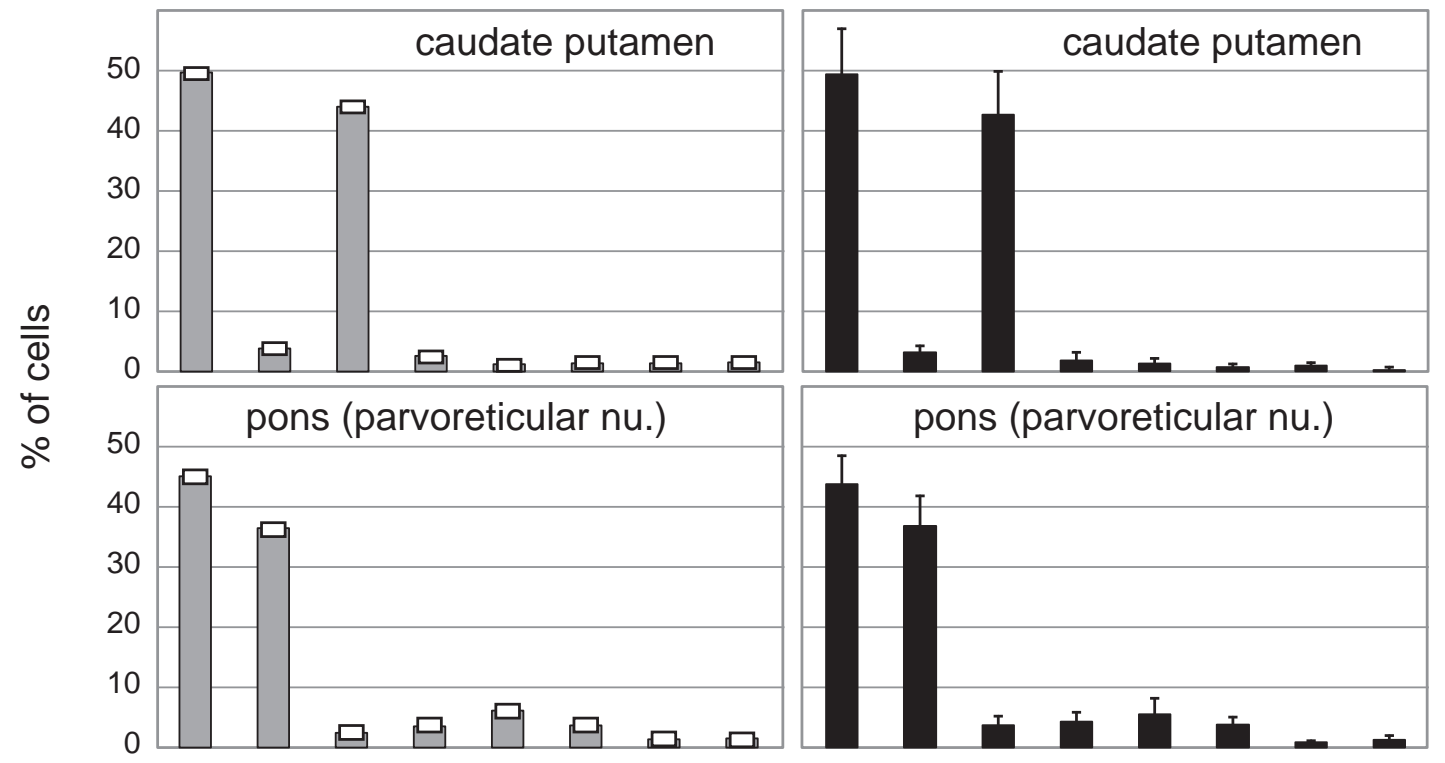

$\begin{array}{rllllllllllllllll}\text { AGAT } & - & + & - & - & + & + & - & + & - & + & - & - & + & + & - & + \\ \text { GAMT } & - & - & + & - & + & - & + & + & - & - & + & - & + & - & + & + \\ \text { SLC6A8 } & - & - & - & + & - & + & + & + & - & - & - & + & - & + & + & +\end{array}$



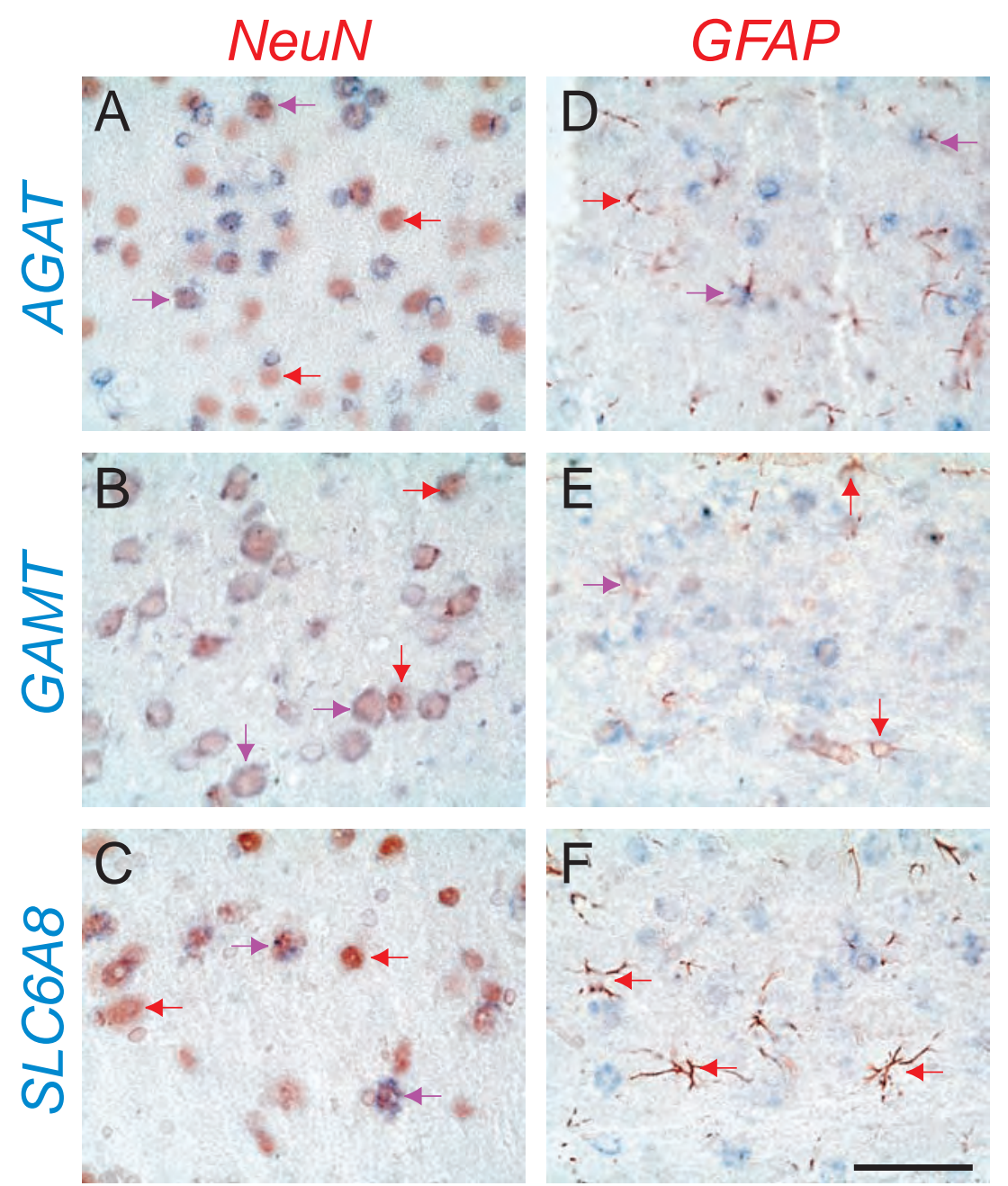

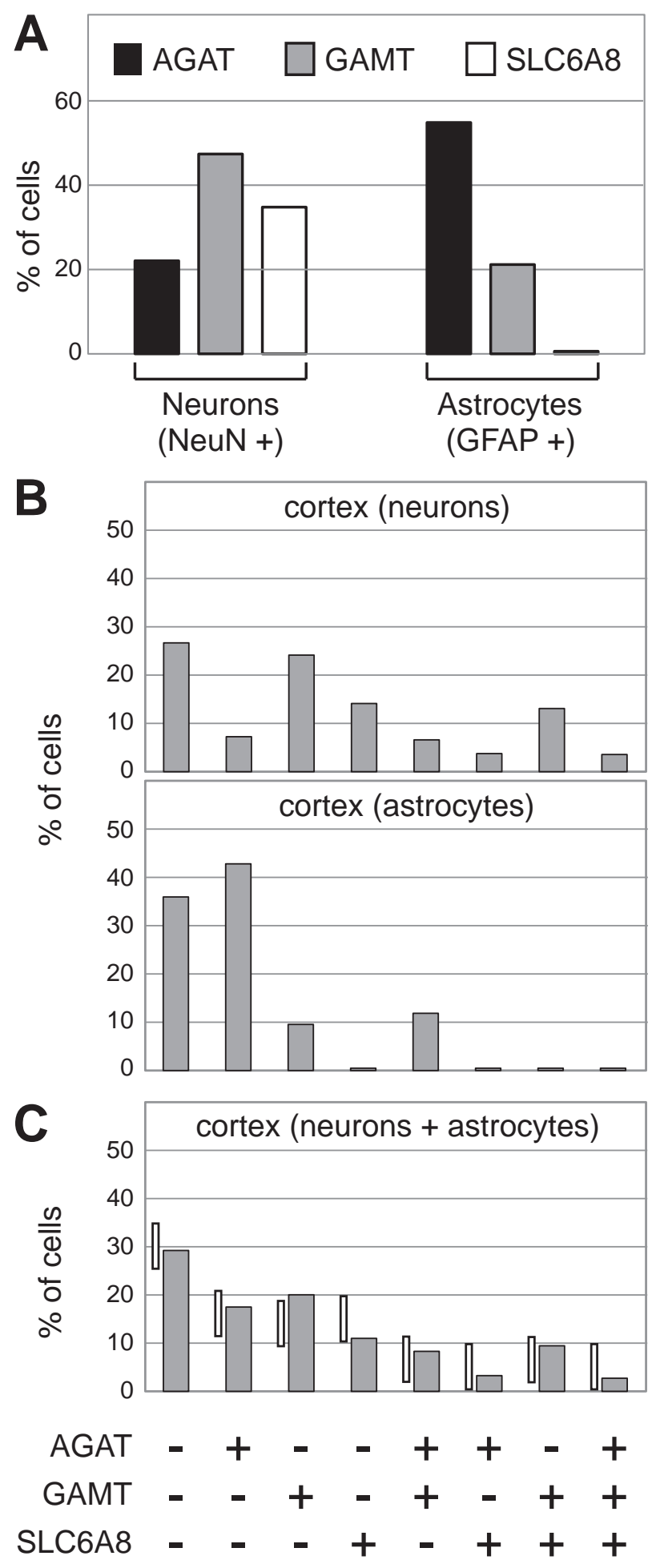

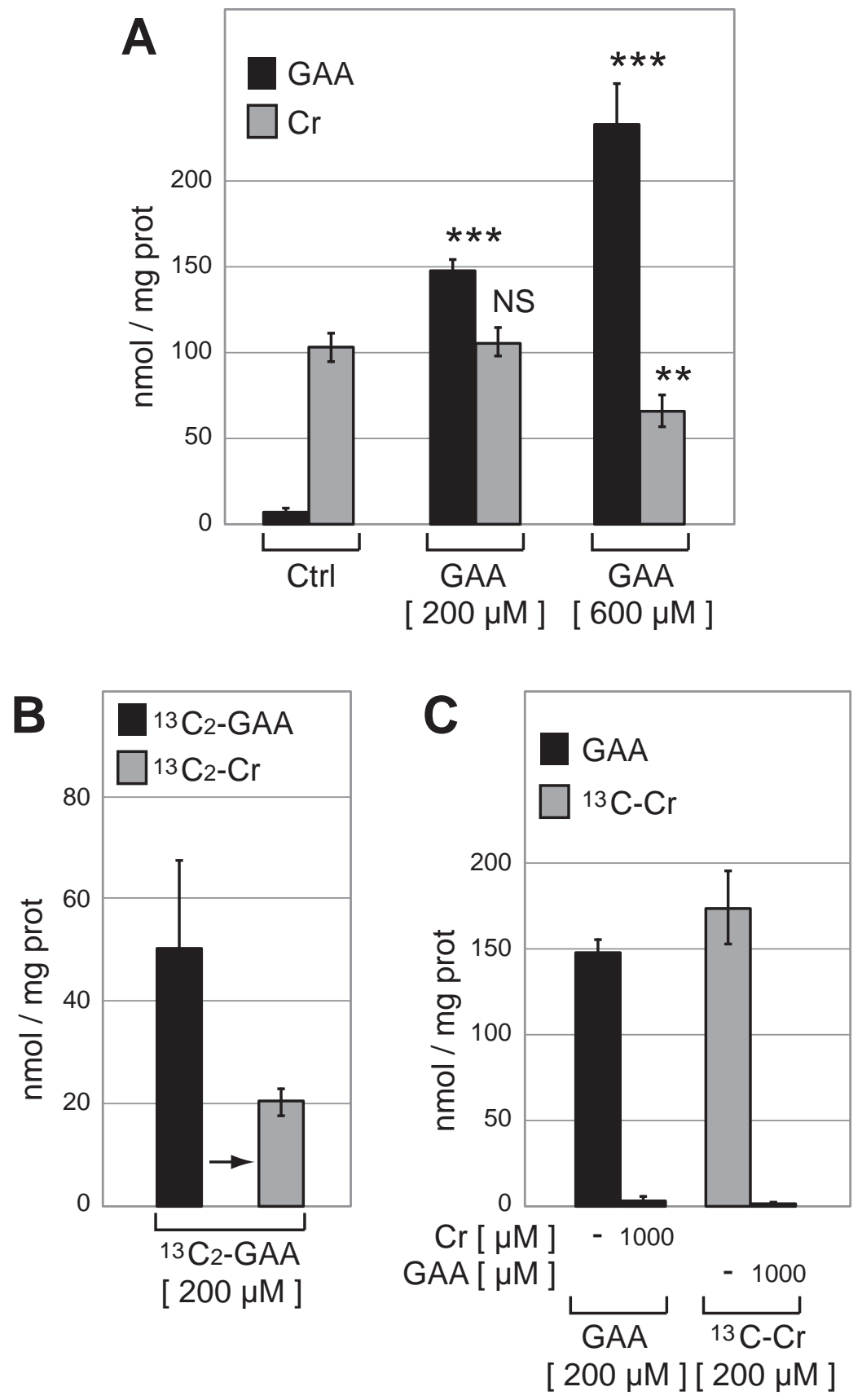


\section{Supplementary Table 1:}

Position of each structure observed of the rat brain, and average number of cells counted, per brain, in each of these structures, and for each " 2 by 2 " co-labeling experiment. $^{\mathrm{a}}$

\begin{tabular}{|c|c|c|c|}
\hline & Antero-posterior : & Dorso-ventral : & $\begin{array}{l}\text { Cells counted / brain } \\
\text { / "2 by 2" co-labeling } \\
\text { experiment }^{\text {b }}\end{array}$ \\
\hline Cortex $(\mathrm{Cx})$ & bregma $-2.00 \mathrm{~mm}$ & interaural $+8.40 \mathrm{~mm}$ & $218 \pm 6$ \\
\hline Caudate putamen (CP) & bregma $+0.60 \mathrm{~mm}$ & interaural $+4.80 \mathrm{~mm}$ & $273 \pm 25$ \\
\hline Hippocampus (CA3) & bregma $-2.20 \mathrm{~mm}$ & interaural $+6.40 \mathrm{~mm}$ & $136 \pm 14$ \\
\hline Hippocampus (DG) & bregma $-3.50 \mathrm{~mm}$ & interaural $+6.50 \mathrm{~mm}$ & $534 \pm 27$ \\
\hline Hypothalamus (VMH) & bregma $-2.80 \mathrm{~mm}$ & interaural $+0.20 \mathrm{~mm}$ & $90 \pm 3$ \\
\hline Inferior colliculus (IC) & bregma $-9.00 \mathrm{~mm}$ & interaural $+6.40 \mathrm{~mm}$ & $170 \pm 9$ \\
\hline Pons (PCRt) & bregma $-12.20 \mathrm{~mm}$ & interaural $+1.15 \mathrm{~mm}$ & $223 \pm 12$ \\
\hline Cerebellum (molecular layer) & bregma $-14.80 \mathrm{~mm}$ & interaural $+5.20 \mathrm{~mm}$ & $102 \pm 4$ \\
\hline Cerebellum (Purkinje neurons) & bregma $-14.60 \mathrm{~mm}$ & interaural $+5.20 \mathrm{~mm}$ & $38 \pm 4$ \\
\hline Cerebellum (Med) & bregma $-11.40 \mathrm{~mm}$ & interaural $+4.20 \mathrm{~mm}$ & $119 \pm 11$ \\
\hline
\end{tabular}

a: The position is according to Paxinos \& Watson (1986; the rat brain in stereotaxic coordinates; London: Academic Press Limited). CA3: giant pyramidal neurons of Ammon's horn 3; DG: granular neurons of dentate gyrus; Med: deep medial cerebellar nucleus; PCRt: parvocellular reticular nucleus (pons); VMH: ventromedial hypothalamic nucleus.

b: Mean \pm standard deviation $(n=4)$. 


\section{Supplementary Table 2:}

Proportions of (co-)labeled cells in the respective " 2 by 2 " co-labeling experiments AGAT+GAMT, AGAT+SLC6A8 and GAMT+SLC6A8 $\left(=x_{1}\right.$ to $x_{12}$; experimental $)$, in function of the " 3 by 3" AGAT+GAMT+SLC6A8 unknown expression proportions (= $y_{1}$ to $\mathbf{y}_{\mathbf{8}}$; calculated). $\mathbf{y}_{\mathbf{1}}$ : no expression of AGAT, GAMT or SLC6A8; $\mathbf{y}_{\mathbf{2}}$ : AGAT only; $\mathbf{y}_{\mathbf{3}}$ : GAMT only; $\mathbf{y}_{\mathbf{4}}$ : SLC6A8 only; $\mathbf{y}_{5}:$ AGAT+GAMT but not SLC6A8; $\mathbf{y}_{\mathbf{6}}$ : AGAT+SLC6A8 but not GAMT; y7: GAMT+SLC6A8 but not AGAT; y8: AGAT+GAMT+SLC6A8 ( $y_{j}$ are also defined in Figure 1B).

$\begin{array}{ccc} & \text { Measured } & \text { Unknown } \\ & \text { experimentally } & \text { proportions } \\ \text { Experiments : } & (=\text { counted }) & \text { to determine }\end{array}$

\begin{tabular}{|c|c|c|c|}
\hline & - & $=\mathrm{x}_{1}$ & $=y_{1}+y_{4}$ \\
\hline Co-labeling & AGAT & $=\mathrm{x}_{2}$ & $=\mathrm{y}_{2}+\mathrm{y}_{6}$ \\
\hline \multirow[t]{2}{*}{$\mathrm{AGAT}+\mathrm{GAMT}$} & GAMT & $=x_{3}$ & $=y_{3}+y_{7}$ \\
\hline & $\mathrm{AGAT}+\mathrm{GAMT}$ & $=\mathrm{x}_{4}$ & $=\mathrm{y}_{5}+\mathrm{y}_{8}$ \\
\hline
\end{tabular}

\begin{tabular}{|c|c|c|c|}
\hline & - & $=x_{5}$ & $=y_{1}+y_{3}$ \\
\hline Co-labeling & AGAT & $=\mathrm{x}_{6}$ & $=y_{2}+y_{5}$ \\
\hline \multirow[t]{2}{*}{ AGAT + SLC6A8 } & SLC6A8 & $=\mathrm{x}_{7}$ & $=y_{4}+y_{7}$ \\
\hline & AGAT+SLC6A8 & $=\mathrm{x}_{8}$ & $=\mathrm{y}_{6}+\mathrm{y}_{8}$ \\
\hline
\end{tabular}

$\begin{array}{lcll} & - & =x_{9} & =y_{1}+y_{2} \\ \text { Co-labeling } & \text { GAMT } & =x_{10} & =y_{3}+y_{5} \\ \text { GAMT + SLC6A8 } & \text { SLC6A8 } & =x_{11} & =y_{4}+y_{6} \\ & \text { GAMT+SLC6A8 } & =x_{12} & =y_{7}+y_{8}\end{array}$




\section{Supplementary Table 3:}

Experimental interval determination for the "3 by 3" AGAT+GAMT+SLC6A8 (co)expression proportions $y_{1}$ to $y_{8}$ in granular neurons of dentate gyrus (hippocampus). Determination of the experimental intervals $\left(=y_{1}\right.$ to $y_{8}$; shown in left columns of Figure 3$)$ is based on the experimental measure (= cell counting; $\mathrm{x}_{\mathrm{i}}$ ) of the proportions of (co-)labeled cells in the respective " 2 by 2 " co-labeling experiments AGAT+GAMT, AGAT+SLC6A8 and GAMT+SLC6A8 $\left(n=4\right.$; mean \pm standard deviation; see Material and Methods; $x_{i}$ are also defined in Supplementary Table 2, while $\mathrm{y}_{\mathrm{j}}$ are also defined in Figure 1B and Supplementary Table 2). The same method of calculation was applied for each brain structure observed.

\begin{tabular}{|c|c|c|}
\hline \multicolumn{3}{|c|}{ Example of hippocampus (granule neurons of dentate gyrus) [\%] } \\
\hline \multicolumn{3}{|c|}{ "2 by 2" co-labeling experiments } \\
\hline AGAT + GAMT & AGAT + SLC6A8 & GAMT + SLC6A8 \\
\hline $\mathrm{x}_{1}=41.4 \pm 7.8$ & $x_{5}=43.9 \pm 9.9$ & $\mathrm{x}_{9}=42.8 \pm 1.3$ \\
\hline $\mathrm{x}_{2}=9.1 \pm 1.3$ & $x_{6}=9.6 \pm 2.1$ & $\mathrm{x}_{10}=10.7 \pm 4.1$ \\
\hline $\mathrm{x}_{3}=10.1 \pm 2.5$ & $x_{7}=7.6 \pm 0.8$ & $\mathrm{x}_{11}=7.7 \pm 2.0$ \\
\hline $\mathrm{x}_{4}=39.4 \pm 6.7$ & $\mathrm{x}_{8}=38.9 \pm 9.8$ & $\mathrm{x}_{12}=38.8 \pm 1.6$ \\
\hline \multirow{4}{*}{$\begin{array}{l}\text { Co-labeling } \\
\text { AGAT + GAMT }\end{array}$} & - & $\mathrm{x}_{1}=\mathrm{y}_{1}+\mathrm{y}_{4}=41.4$ \\
\hline & AGAT & $\mathrm{x}_{2}=\mathrm{y}_{2}+\mathrm{y}_{6}=9.1$ \\
\hline & GAMT & $\mathrm{x}_{3}=\mathrm{y}_{3}+\mathrm{y}_{7}=10.1$ \\
\hline & AGAT+GAMT & $\mathrm{x}_{4}=\mathrm{y}_{5}+\mathrm{y}_{8}=39.4$ \\
\hline \multirow{4}{*}{$\begin{array}{l}\text { Co-labeling } \\
\text { AGAT + SLC6A8 }\end{array}$} & - & $\mathrm{x}_{5}=\mathrm{y}_{1}+\mathrm{y}_{3}=43.9$ \\
\hline & AGAT & $\mathrm{x}_{6}=\mathrm{y}_{2}+\mathrm{y}_{5}=9.6$ \\
\hline & SLC6A8 & $x_{7}=y_{4}+y_{7}=7.6$ \\
\hline & AGAT+SLC6A8 & $\mathrm{x}_{8}=\mathrm{y}_{6}+\mathrm{y}_{8}=38.9$ \\
\hline \multirow{4}{*}{$\begin{array}{l}\text { Co-labeling } \\
\text { GAMT + SLC6A8 }\end{array}$} & - & $\mathrm{x}_{9}=\mathrm{y}_{1}+\mathrm{y}_{2}=42.8$ \\
\hline & GAMT & $\mathrm{x}_{10}=\mathrm{y}_{3}+\mathrm{y}_{5}=10.7$ \\
\hline & SLC6A8 & $\mathrm{x}_{11}=\mathrm{y}_{4}+\mathrm{y}_{6}=7.7$ \\
\hline & GAMT+SLC6A8 & $\mathrm{x}_{12}=\mathrm{y}_{7}+\mathrm{y}_{8}=38.8$ \\
\hline \multicolumn{3}{|c|}{ "3 by 3" (co-)expression interval determination, in function of $y_{4}(=>0 \leq y 4 \leq 7.6$} \\
\hline $\mathbf{y}_{1}:-$ & $\mathrm{y}_{1}=41.4-\mathrm{y}_{4}$ & $33.8 \leq y_{1} \leq 41.4$ \\
\hline $\mathbf{y}_{2}:$ AGAT & $\mathrm{y}_{2}=1.4+\mathrm{y}_{4}$ & $1.4 \leq y_{2} \leq 9.0$ \\
\hline $\mathbf{y}_{3}:$ GAMT & $\mathrm{y}_{3}=2.5+\mathrm{y}_{4}$ & $2.5 \leq y_{3} \leq 10.1$ \\
\hline$Y_{4}:$ SLC6A8 & & $0.0 \leq y_{4} \leq 7.6$ \\
\hline $\mathbf{y}_{5}:$ AGAT+GAMT & $\mathrm{y}_{5}=8.2-\mathrm{y}_{4}$ & $0.6 \leq y_{5} \leq 8.2$ \\
\hline $\mathrm{y}_{6}: \mathrm{AGAT}+\mathrm{SLC6A8}$ & $\mathrm{y}_{6}=7.7-\mathrm{y}_{4}$ & $0.1 \leq \mathrm{y}_{6} \leq 7.7$ \\
\hline $\mathbf{y}_{7}: \mathbf{G A M T}+\mathbf{S L C 6 A 8}$ & $\mathrm{y}_{7}=7.6-\mathrm{y}_{4}$ & $0.0 \leq y_{7} \leq 7.6$ \\
\hline $\mathrm{y}_{8}: \mathrm{AGAT}+\mathrm{GAMT}+\mathrm{SLC6A8}$ & $\mathrm{y}_{8}=31.2+\mathrm{y}_{4}$ & $31.8 \leq y_{8} \leq 38.8$ \\
\hline
\end{tabular}




\section{Supplementary Table 4:}

Calculation of the "3 by 3" AGAT+GAMT+SLC6A8 (co-)expression proportions $\mathrm{y}_{1}$ to y8$_{8}$, based on the hypothesis that AGAT, GAMT and SLC6A8 are expressed independent of each other in brain cells. For each $y_{1}$ to $y_{8}$ unknowns, 3 different (but equivalent) equations can be developed. An example is given for granular neurons of the dentate gyrus (hippocampus) (see also Material and Methods, as well as Figure 1B and Supplementary Table 2). The same method of calculation was applied for each brain structure observed. The means obtained ( \pm standard deviations, are shown in right columns of Figure 3 ).

Example of hippocampus (granular neurons of dentate gyrus) [\%]

\begin{tabular}{|c|c|c|}
\hline $\mathbf{y}_{1}$ & $:-$ & \\
\hline \multirow[t]{4}{*}{$\mathrm{y}_{1}$} & $=\mathrm{x}_{1}-\left[\mathrm{x}_{7} /\left(\mathrm{x}_{7}+\mathrm{x}_{5}\right) * \mathrm{x}_{1}\right]$ & 35.3 \\
\hline & $=\mathrm{x}_{5}-\left[\mathrm{x}_{10} /\left(\mathrm{x}_{10}+\mathrm{x}_{9}\right) * \mathrm{x}_{5}\right]$ & 35.1 \\
\hline & $=\mathrm{x}_{9}-\left[\mathrm{x}_{2} /\left(\mathrm{x}_{2}+\mathrm{x}_{1}\right) * \mathrm{x}_{9}\right]$ & 35.1 \\
\hline & & 35.2 \\
\hline
\end{tabular}

\begin{tabular}{|c|c|c|}
\hline 5 & : AGAT+GAMT & \\
\hline$y_{5}$ & $=\mathrm{x}_{4}-\left[\mathrm{x}_{8} /\left(\mathrm{x}_{8}+\mathrm{x}_{6}\right) * \mathrm{x}_{4}\right]$ & 7.8 \\
\hline & $=\mathrm{x}_{6}-\left[\mathrm{x}_{9} /\left(\mathrm{x}_{9}+\mathrm{x}_{10}\right) * \mathrm{x}_{6}\right]$ & 1.9 \\
\hline & $=\mathrm{x}_{10}-\left[\mathrm{x}_{3} /\left(\mathrm{x}_{3}+\mathrm{x}_{4}\right) * \mathrm{x}_{10}\right]$ & 8.5 \\
\hline
\end{tabular}

\begin{tabular}{rlr}
$\mathrm{y}_{2}$ & $:$ AGAT \\
$\mathrm{y}_{2}$ & $=\mathrm{x}_{2}-\left[\mathrm{x}_{8} /\left(\mathrm{x}_{8}+\mathrm{x}_{6}\right) * \mathrm{x}_{2}\right]$ & \\
& $=\mathrm{x}_{6}-\left[\mathrm{x}_{10} /\left(\mathrm{x}_{10}+\mathrm{x}_{9}\right) * \mathrm{x}_{6}\right]$ & \\
& $=\mathrm{x}_{9}-\left[\mathrm{x}_{1} /\left(\mathrm{x}_{1}+\mathrm{x}_{2}\right) * \mathrm{x}_{9}\right]$ & \\
& & 7.7 \\
\hline & mean : & 5.7
\end{tabular}

\begin{tabular}{|c|c|c|}
\hline$y_{6}$ & : AGAT+SLC6A8 & \\
\hline \multirow[t]{3}{*}{$\mathrm{y}_{6}$} & $=\mathrm{x}_{2}-\left[\mathrm{x}_{9} /\left(\mathrm{x}_{9}+\mathrm{x}_{11}\right) * \mathrm{x}_{2}\right]$ & 1.4 \\
\hline & $=\mathrm{x}_{8}-\left[\mathrm{x}_{4} /\left(\mathrm{x}_{4}+\mathrm{x}_{2}\right)^{*} \mathrm{x}_{8}\right]$ & 7.3 \\
\hline & $=\mathrm{x}_{11}-\left[\mathrm{x}_{7} /\left(\mathrm{x}_{7}+\mathrm{x}_{8}\right) * \mathrm{x}_{11}\right]$ & 6.4 \\
\hline
\end{tabular}

\begin{tabular}{|c|c|c|}
\hline $\mathbf{y}_{3}$ & : GAMT & \\
\hline \multirow[t]{4}{*}{$\mathrm{y}_{3}$} & $=\mathrm{x}_{3}-\left[\mathrm{x}_{12} /\left(\mathrm{x}_{12}+\mathrm{x}_{10}\right) * \mathrm{x}_{3}\right]$ & 2.2 \\
\hline & $=\mathrm{x}_{5}-\left[\mathrm{x}_{1} /\left(\mathrm{x}_{1}+\mathrm{x}_{3}\right) * \mathrm{x}_{5}\right]$ & 8.6 \\
\hline & $=\mathrm{x}_{10}-\left[\mathrm{x}_{6} /\left(\mathrm{x}_{6}+\mathrm{x}_{5}\right)^{*} \mathrm{x}_{10}\right]$ & 8.8 \\
\hline & & 6.5 \\
\hline
\end{tabular}

\begin{tabular}{|c|c|c|}
\hline $\mathbf{y}_{7}$ & : GAMT+SLC6A8 & \\
\hline \multirow[t]{3}{*}{$\mathrm{y}_{7}$} & $=\mathrm{x}_{3}-\left[\mathrm{x}_{5} /\left(\mathrm{x}_{5}+\mathrm{x}_{7}\right) * \mathrm{x}_{3}\right]$ & 1.5 \\
\hline & $=\mathrm{x}_{7}-\left[\mathrm{x}_{11} /\left(\mathrm{x}_{11}+\mathrm{x}_{12}\right) * \mathrm{x}_{7}\right]$ & 6.3 \\
\hline & $=\mathrm{x}_{12}-\left[\mathrm{x}_{4} /\left(\mathrm{x}_{4}+\mathrm{x}_{3}\right) * \mathrm{x}_{12}\right]$ & 7.9 \\
\hline
\end{tabular}

\begin{tabular}{|c|c|c|}
\hline & : SLC6A8 & \\
\hline \multirow[t]{4}{*}{$\mathrm{y}_{4}$} & $=\mathrm{x}_{1}-\left[\mathrm{x}_{9} /\left(\mathrm{x}_{9}+\mathrm{x}_{11}\right) * \mathrm{x}_{1}\right]$ & 6.3 \\
\hline & $=\mathrm{x}_{7}-\left[\mathrm{x}_{3} /\left(\mathrm{x}_{3}+\mathrm{x}_{1}\right) * \mathrm{x}_{7}\right]$ & 6.1 \\
\hline & $=\mathrm{x}_{11}-\left[\mathrm{x}_{8} /\left(\mathrm{x}_{8}+\mathrm{x}_{7}\right) * \mathrm{x}_{11}\right]$ & 1.3 \\
\hline & & 4.6 \\
\hline
\end{tabular}

$\begin{array}{rlr}\mathbf{y}_{8} & : \text { AGAT+GAMT+SLC6A8 } & \\ \mathrm{y}_{8} & =\mathrm{x}_{4}-\left[\mathrm{x}_{10} /\left(\mathrm{x}_{10}+\mathrm{x}_{12}\right) * \mathrm{x}_{4}\right] & 30.9 \\ & =\mathrm{x}_{8}-\left[\mathrm{x}_{2} /\left(\mathrm{x}_{2}+\mathrm{x}_{4}\right) * \mathrm{x}_{8}\right] & 31.6 \\ & =\mathrm{x}_{12}-\left[\mathrm{x}_{7} /\left(\mathrm{x}_{7}+\mathrm{x}_{8}\right) * \mathrm{x}_{12}\right] & 32.5 \\ {\text { mean : }} &{31.6}\end{array}$

